\title{
The Neuropathic Itch Caused by Pseudorabies Virus
}

\author{
Kathlyn Laval * and Lynn W. Enquist \\ Department of Molecular Biology, Princeton University, Princeton, NJ 08540, USA; lenquist@princeton.edu \\ * Correspondence: klaval@princeton.edu
}

Received: 23 February 2020; Accepted: 25 March 2020; Published: 31 March 2020

\begin{abstract}
Pseudorabies virus (PRV) is an alphaherpesvirus related to varicella-zoster virus (VZV) and herpes simplex virus type 1 (HSV1). PRV is the causative agent of Aujeskzy's disease in swine. PRV infects mucosal epithelium and the peripheral nervous system (PNS) of its host where it can establish a quiescent, latent infection. While the natural host of PRV is the swine, a broad spectrum of mammals, including rodents, cats, dogs, and cattle can be infected. Since the nineteenth century, PRV infection is known to cause a severe acute neuropathy, the so called "mad itch" in non-natural hosts, but surprisingly not in swine. In the past, most scientific efforts have been directed to eradicating PRV from pig farms by the use of effective marker vaccines, but little attention has been given to the processes leading to the mad itch. The main objective of this review is to provide state-of-the-art information on the mechanisms governing PRV-induced neuropathic itch in non-natural hosts. We highlight similarities and key differences in the pathogenesis of PRV infections between non-natural hosts and pigs that might explain their distinctive clinical outcomes. Current knowledge on the neurobiology and possible explanations for the unstoppable itch experienced by PRV-infected animals is also reviewed. We summarize recent findings concerning PRV-induced neuroinflammatory responses in mice and address the relevance of this animal model to study other alphaherpesvirus-induced neuropathies, such as those observed for VZV infection.
\end{abstract}

Keywords: Pseudorabies virus; neuropathic itch; immunopathogenesis; neuropathogenesis; swine; non-natural hosts; neuroinflammation

\section{History of Aujeszky's Disease}

In 1813, a disease in cattle characterized by intense itching was first described in the USA. A similar disease appeared in Switzerland in 1849 and was mistaken for rabies because of the similar symptoms observed in cattle and dogs. In 1902, Aladár Aujeszky, a Hungarian veterinarian, first demonstrated the infectious nature of the agent and was able to distinguish the disease from rabies after experimental inoculation of rabbits with tissue suspensions from a diseased ox, a dog, and a cat. The infected rabbits showed excitation and nasal pruritus followed by convulsions and died within $60 \mathrm{~h}$ post-inoculation (hpi) [1]. Thus, the disease became known as "Aujeszky's disease" (AD). In 1910, Schmiedhoffer confirmed that the disease was caused by a virus by performing filtration experiments [2]. From 1902 to 1930, only single outbreaks of AD were reported mainly in cattle and dogs in Hungary, Romania, France, Russia, and Brazil and the USA. At that time, the name "pseudorabies" was given to the disease in Europe because of its similarity to clinical rabies, while the term "mad itch" was mainly used in the USA. In 1931, Shope finally reported that mad itch and pseudorabies were caused by the same virus [3]. Three years later, he demonstrated that the agent of "mad itch" in cattle was also present in swine [4]. He also noted that the disease spread in swine herd and that, if cattle were pastured in the same lot, transmission from swine to cattle took place through abrasion of cattle skin. Surprisingly, the disease was not transmitted from cow to cow. In 1931, the Netherlands was the first country where the virus was reported to be enzootic in pigs. In the following years, sporadic outbreaks of PRV in pigs 
occurred worldwide and pigs were identified as a reservoir for the virus. In 1934, Sabin and Wright reported that $\mathrm{AD}$ virus (ADV)/pseudorabies virus (PRV) was serologically related to herpes simplex virus (HSV), resulting in the classification of the virus into the herpesvirus group [5-7].

\section{Case Reports of Neuropathic Itch Caused by PRV Infection in Non-Natural Hosts}

Since the 1950s, PRV remained a major pathogen in swine due to the intensification of pig production worldwide, resulting in severe economic losses to the pig industry. Efforts have been directed primarily to eradicating PRV from pig farms by the use of effective marker vaccines, but few studies have focused on the pathogenesis of the mad itch [8]. For the most part, this is because the characteristic pruritus observed in PRV-infected cattle and other hosts is not a common clinical symptom in infected pigs. Although, in many European countries and in the United States, PRV has been eliminated from domestic pigs, the virus continues to circulate among wild boar and feral swine, which act as a reservoir for the virus.

Many cases of PRV infection in non-natural hosts have been reported since the 1950s. In this review, we summarize all the major findings since 2004 (See Table 1). A total of 26 cases of PRV infection have been reported involving a total of 13 humans, 50 dogs, 2 cats, 6 cattle, 863 sheep, 3 goats, 3931 captive mink, 1 wild and 1200 captive foxes, 1 wolf, and 1 lynx. The case reports of PRV-infected animals occurred primarily in European countries, USA and China and resulted from direct contact with pigs while hunting or through the consumption of raw offal from infected pigs (wild and domesticated) or pig carcasses. The main characteristic clinical symptoms observed in all infected animals were severe pruritus in the head and neck areas accompanied by self-mutilation. All infected animals usually died within $24-48 \mathrm{~h}$ after the disease onset. Gross postmortem examination of all infected animals revealed purulent edema and inflammation of the subcutaneous tissues of the scratched area, hyperemia, and hemorrhages. On histopathological examination, perivascular infiltrates of neutrophils, lymphocytes, and a few macrophages were observed in the brainstem, medulla oblongata, meninges and trigeminal ganglia (TG). Neuronal degeneration and necrosis as well as gliosis, satellitosis, and the presence of intranuclear inclusion bodies within neurons, astrocytes and satellite cells were also noted. The presence of infectious PRV and PRV DNA was confirmed by virus isolation, immunohistochemistry (IHC) and polymerase chain reaction (PCR) on brain and TG samples obtained from dead animals.

In contrast, case reports for humans consisted mainly of patients hospitalized with fever, headaches, visual impairment, seizures, respiratory failure, and coma within 1-3 days after the appearance of the symptoms. No signs of pruritus with self-mutilation were observed. Brain magnetic resonance imaging (MRI) and computed tomography (CT) scans showed abnormal signals in the insular cortex, bilateral temporal lobes, and hippocampus. Patients were usually diagnosed with viral encephalitis with the exception of one who was diagnosed with endophthalmitis. All patients immediately received antiviral therapy (acyclovir) for approximately 2 weeks. Gross pathological examination was not applicable as all patients survived with the exception of one who died after failing to respond to antiviral treatment [9]. Unfortunately, an autopsy was not performed on this patient. The presence of PRV DNA was confirmed by PCR of the vitreous humor of one patient with endophthalmitis [10]. Next generation sequencing (NGS) was used to detect only a number of 2-74 unique sequence reads of PRV, and no other viruses, in cerebrospinal fluid (CSF) of patients. It was suggested that the use of antivirals before detection might be the main reason for the limited number of virus sequences detected. Serological tests confirmed the presence of PRV antibodies in the serum and CSF of those patients. However, the presence of PRV was never determined by virus isolation from vitreous humor or CSF samples to confirm its infectivity. Interestingly, all case reports in humans occurred in China and mainly resulted from eye and hand injuries of patients at work (pig farms or slaughterhouses). The high incidence of suspected human PRV infections identified here might to be related to the high prevalence of PRV in swine in China and repeated exposure to infected animal tissues [11,12]. Still, it is important to keep in mind that these incidences are not unique development within China or occur just recently, as previously described by [13]. 
The absence of pruritus in all infected patients resembles the clinical outcome of PRV infection in swine and may suggest important differences in the pathogenesis of PRV among humans, swine, and all other non-natural hosts. There is a strong evidence that PRV-induced neuropathology and the clinical outcome of infection are connected with the innate immune response. Still, it is not clear whether humans have developed a more controlled and effective immune response (similar to swine) against PRV infection than other non-natural hosts. In the following sections, we will discuss in more detail similarities and key differences in the neuropathogenesis and immunopathogenesis of PRV infections between non-natural hosts and pigs that might explain their distinctive clinical outcomes.

\section{Pseudorabies Virus (PRV)}

In this section, we provide basic information about PRV taxonomy and virion structure, which is useful to understand PRV pathogenesis. The replication cycle of PRV as well as the cell-associated spread of infection are not covered in this review as several excellent reviews already addressed these topics in detail [14-16].

PRV belongs to the family of the Herpesviridae, subfamily Alphaherpesvirinae, genus Varicellovirus. The virus is closely related to herpes simplex virus type 1 and 2 (HSV1 and HSV2) and varicella-zoster virus (VZV), causing cold sores, genital lesions, and chicken pox, respectively [17]. The virion is $150-180 \mathrm{~nm}$ in diameter and comprises four main structural components: Genome, capsid, tegument, and envelope. The viral genome consists of a linear double stranded DNA of approximately $150 \mathrm{kbp}$. The complete genome contains at least 70 open reading frames. The genome consists of a long unique region (UL) flanked by a short inverted repeat (TRL/IRL) linked to a short unique region (Us) flanked by an inverted repeat (TRS/IRS) [18-20]. The genome is enclosed in an icosahedral capsid, consisting of 162 capsomers. The genome and capsid together form the nucleocapsid that is surrounded by the tegument, a proteinaceous matrix that lines the space between the nucleocapsid and the envelope. Tegument proteins play an important role during virus entry, assembly, and egress [21]. The envelope consists of a bilayer of phospholipids derived from the trans-Golgi network of the host cell and contains different embedded glycoproteins. For PRV, 11 glycoproteins have been characterized ( $\mathrm{gB}, \mathrm{gC}, \mathrm{gD}, \mathrm{gE}, \mathrm{gG}, \mathrm{gH}, \mathrm{gI}, \mathrm{gK}, \mathrm{gL}, \mathrm{gM}$, and $\mathrm{gN}$ ) and named according to the nomenclature established for the related proteins of HSV-1 [15,16,22]. All glycoproteins are constituents of the virion, except gG, which is secreted into the medium by infected cells [23]. The envelope proteins play important roles in virion binding and entry, envelopment, egress, cell-to-cell spread, induction of protective immunity, and immune evasion $[15,16]$. 
Table 1. Case reports of neuropathic itch caused by pseudorabies virus (PRV) infection in non-natural hosts since 2004.

\begin{tabular}{|c|c|c|c|c|c|c|c|c|c|c|}
\hline Case $n^{\circ}$ & $\begin{array}{c}\text { Year of } \\
\text { Occurrence }\end{array}$ & Country & $\begin{array}{l}\text { Species and } \\
\text { Number of } \\
\text { Confirmed } \\
\text { Cases }\end{array}$ & $\begin{array}{c}\text { Source of } \\
\text { Contamination }\end{array}$ & $\begin{array}{c}\text { Characteristic Clinical } \\
\text { Symptoms }\end{array}$ & Gross Pathology & $\begin{array}{l}\text { Histological } \\
\text { Findings }\end{array}$ & $\begin{array}{l}\text { Death after } \\
\text { Onset of } \\
\text { Clinical } \\
\text { Symptoms }\end{array}$ & PRV Detection & Publication \\
\hline 1 & 2004 & Poland & $\begin{array}{c}\text { Farm animals: } \\
7 \text { cattle, } 3 \text { goats, } \\
3 \text { sheep, } 2 \text { cats } \\
\text { and } 1 \text { dog }\end{array}$ & Not clear & $\begin{array}{l}\text {-Local pruritus with } \\
\text { violent licking, chewing } \\
\text { and rubbing of various } \\
\text { body parts } \\
\text {-Fever } \\
\text {-Excessive salivation }\end{array}$ & Not specified & Not specified & $48 \mathrm{~h}$ & $\begin{array}{l}\text { Virus isolation } \\
\text { and PCR on } \\
\text { brain and } \\
\text { internal organs } \\
\text { samples }\end{array}$ & [24] \\
\hline 2 & 2006 & Austria & 1 hunting dog & $\begin{array}{l}\text { Contact with } \\
\text { feral swine } \\
\text { while hunting }\end{array}$ & $\begin{array}{l}\text {-Severe pruritus on the } \\
\text { lip with self-mutilation } \\
\text {-Fever } \\
\text {-Tachypnea } \\
\text {-Seizures }\end{array}$ & $\begin{array}{l}\text {-Purulent edema of } \\
\text { the lip } \\
\text {-Hypertrophied heart } \\
\text { and hyperemia }\end{array}$ & $\begin{array}{l}\text {-Non purulent } \\
\text { encephalitis with } \\
\text { intranuclear } \\
\text { inclusion bodies } \\
\text {-Multifocal } \\
\text { lymphohistiocytic } \\
\text { perivascular } \\
\text { infiltrate in the } \\
\text { medulla oblongata } \\
\text {-Multifocal necrosis } \\
\text { ganglia }\end{array}$ & $24 \mathrm{~h}$ & $\begin{array}{l}\text { H\&E staining, } \\
\text { IHC, virus } \\
\text { isolation and } \\
\text { PCR on brain } \\
\text { samples }\end{array}$ & {$[25,26]$} \\
\hline 3 & 2007 & Belgium & 2 hunting dogs & $\begin{array}{l}\text { Eaten offal from } \\
\text { a wild boar }\end{array}$ & $\begin{array}{l}\text {-Intense facial pruritus } \\
\text { with self-mutilation } \\
\text {-Convulsions } \\
\text {-Hypersalivation }\end{array}$ & Not specified & Not specified & $24 \mathrm{~h}$ & $\begin{array}{l}\text { Virus isolation } \\
\text { and qPCR on } \\
\text { brain samples }\end{array}$ & [27] \\
\hline 4 & 2008 & Spain & 30 minks & $\begin{array}{l}\text { Eaten swine } \\
\text { viscera } \\
\text { incorporated to } \\
\text { food mixture }\end{array}$ & Not specified & $\begin{array}{l}\text { Hemorrhages, } \\
\text { ischemia and } \\
\text { systemic } \\
\text { vasculopathy }\end{array}$ & $\begin{array}{l}\text { Mild purulent } \\
\text { ganglioneuritis and } \\
\text { encephalomyelitis }\end{array}$ & $48 \mathrm{~h}$ & $\begin{array}{l}\text { IHC and PCR on } \\
\text { oropharyngeal } \\
\text { mucosa, TG, } \\
\text { spinal cord and } \\
\text { brain samples }\end{array}$ & [28] \\
\hline 5 & 2008-2010 & Austria & 6 hunting dogs & $\begin{array}{l}\text { Contact to the } \\
\text { shot boars }\end{array}$ & $\begin{array}{l}\text {-Intense pruritus on the } \\
\text { neck and shoulders with } \\
\text { self-mutilation } \\
\text {-Hypersalivation } \\
\text {-Coma }\end{array}$ & $\begin{array}{l}\text {-Itch associated } \\
\text { lesions in the head } \\
\text { area } \\
\text {-Purulent } \\
\text { inflammation and } \\
\text { edema of the } \\
\text { subcutaneous tissues }\end{array}$ & $\begin{array}{l}\text { Non purulent } \\
\text { encephalitis of the } \\
\text { brainstem with } \\
\text { intranuclear } \\
\text { inclusion bodies }\end{array}$ & $16-44 \mathrm{~h}$ & $\begin{array}{l}\mathrm{IHC} \text { and PCR on } \\
\text { brain samples }\end{array}$ & {$[25,29]$} \\
\hline 6 & 2011 & USA & 3 hunting dogs & $\begin{array}{l}\text { Contact with } \\
\text { feral swine } \\
\text { while hunting }\end{array}$ & $\begin{array}{l}\text {-Intense facial pruritus } \\
\text { with self-mutilation } \\
\text {-Fever } \\
\text {-Dyspnea } \\
\text {-Vomiting } \\
\text {-Muscle stiffness }\end{array}$ & $\begin{array}{l}\text { Extensive } \\
\text { subendocardial } \\
\text { hemorrhage }\end{array}$ & $\begin{array}{l}\text { Neutrophilic } \\
\text { trigeminal } \\
\text { ganglioneuritis }\end{array}$ & $48 \mathrm{~h}$ & $\begin{array}{l}\text { IHC and IF on } \\
\text { TG samples }\end{array}$ & [30] \\
\hline
\end{tabular}


Table 1. Cont.

\begin{tabular}{|c|c|c|c|c|c|c|c|c|c|c|}
\hline Case $^{\circ}$ & $\begin{array}{c}\text { Year of } \\
\text { Occurrence }\end{array}$ & Country & $\begin{array}{l}\text { Species and } \\
\text { Number of } \\
\text { Confirmed } \\
\text { Cases }\end{array}$ & $\begin{array}{c}\text { Source of } \\
\text { Contamination }\end{array}$ & $\begin{array}{c}\text { Characteristic Clinical } \\
\text { Symptoms }\end{array}$ & Gross Pathology & $\begin{array}{l}\text { Histological } \\
\text { Findings }\end{array}$ & $\begin{array}{l}\text { Death after } \\
\text { Onset of } \\
\text { Clinical } \\
\text { Symptoms }\end{array}$ & PRV Detection & Publication \\
\hline 7 & $2011-2013$ & China & $\begin{array}{c}13 \text { farm and pet } \\
\text { dogs }\end{array}$ & $\begin{array}{l}\text { Possible contact } \\
\text { with infected } \\
\text { pigs or } \\
\text { consumption of } \\
\text { raw meat }\end{array}$ & $\begin{array}{l}\text {-Pruritus } \\
\text {-Tachypnea } \\
\text {-Dyspnea }\end{array}$ & $\begin{array}{l}\text { Systemic } \\
\text { hemorrhage }\end{array}$ & $\begin{array}{l}\text {-Non suppurative } \\
\text { encephalitis with } \\
\text { severe perivascular } \\
\text { cuffing and glia cell } \\
\text { proliferation }\end{array}$ & Not specified & $\begin{array}{l}\text { Virus isolation } \\
\text { and PCR on } \\
\text { brain samples }\end{array}$ & [31] \\
\hline 8 & 2012 & Germany & 1 hunting dog & Not specified & $\begin{array}{l}\text {-Tremors } \\
\text {-Trismus } \\
\text {-Spasms of the } \\
\text { musculature of the larynx } \\
\text { and pharynx } \\
\text {-Dyspnea } \\
\text {-Vomiting }\end{array}$ & Not specified & $\begin{array}{l}\text { Non suppurative } \\
\text { encephalitis in the } \\
\text { brainstem with } \\
\text { perivascular cuffing } \\
\text { of lymphocytes and } \\
\text { macrophages }\end{array}$ & Not specified & $\begin{array}{l}\text { IHC on TG and } \\
\text { brain samples }\end{array}$ & [32] \\
\hline 9 & 2012 & China & 860 sheep & $\begin{array}{l}\text { Vaccinated with } \\
\text { live-attenuated } \\
\text { PRV-Bartha K16 } \\
\text { strain }\end{array}$ & $\begin{array}{l}\text {-Intense rubbing and } \\
\text { licking with } \\
\text { self-mutilation in the area } \\
\text { where the vaccine was } \\
\text { injected } \\
\text {-Localized pruritus } \\
\text {-Fever } \\
\text {-Paralysis } \\
\text {-Dyspnea }\end{array}$ & None & Not specified & $24 \mathrm{~h}$ & $\begin{array}{l}\text { PCR and EM on } \\
\text { brain samples }\end{array}$ & [33] \\
\hline 10 & 2010-2014 & Italy & $\begin{array}{l}11 \text { hunting } \\
\text { dogs }\end{array}$ & $\begin{array}{l}\text { Direct contact } \\
\text { with infected } \\
\text { pigs or fed with } \\
\text { raw meat }\end{array}$ & $\begin{array}{l}\text {-Intense facial pruritus } \\
\text {-Tremors } \\
\text {-Dyspnea }\end{array}$ & $\begin{array}{l}\text { Acute pulmonary } \\
\text { alveolar emphysema } \\
\text { and edema }\end{array}$ & Not specified & $24-48 \mathrm{~h}$ & $\begin{array}{l}\text { IHC on brain } \\
\text { samples }\end{array}$ & [34] \\
\hline 11 & 2014 & Italy & 1 wild fox & $\begin{array}{l}\text { Contact with } \\
\text { infected } \\
\text { domestic } \\
\text { swine/feeding } \\
\text { on infected } \\
\text { rodents }\end{array}$ & $\begin{array}{l}\text {-Head scratching } \\
\text {-Motor coordination } \\
\text {-Rolling in the snow }\end{array}$ & $\begin{array}{l}\text {-Subcutaneous } \\
\text { edema (head) } \\
\text {-Multiple skin } \\
\text { abrasions from } \\
\text { scratching }\end{array}$ & Not specified & $48 \mathrm{~h}$ & $\begin{array}{l}\text { Virus isolation } \\
\text { on brain } \\
\text { samples }\end{array}$ & [35] \\
\hline 12 & 2014 & China & 379 minks & $\begin{array}{l}\text { Captive minks } \\
\text { fed raw pork } \\
\text { livers }\end{array}$ & $\begin{array}{l}\text {-Abdominal and facial } \\
\text { pruritus } \\
\text {-Claw and cage biting } \\
\text {-Dyspnea- } \\
\text { Vomiting }\end{array}$ & $\begin{array}{l}\text {-Systemic } \\
\text { hemorrhage } \\
\text {-Splenic lesions } \\
\text {-Petechia and } \\
\text { ecchymoses in the } \\
\text { epicardia }\end{array}$ & Not specified & $24-48 \mathrm{~h}$ & $\begin{array}{l}\text { Virus isolation } \\
\text { and IF on brain } \\
\text { samples }\end{array}$ & [36] \\
\hline
\end{tabular}


Table 1. Cont

\begin{tabular}{|c|c|c|c|c|c|c|c|c|c|c|}
\hline Case $^{\circ}$ & $\begin{array}{c}\text { Year of } \\
\text { Occurrence }\end{array}$ & Country & $\begin{array}{l}\text { Species and } \\
\text { Number of } \\
\text { Confirmed } \\
\text { Cases }\end{array}$ & $\begin{array}{c}\text { Source of } \\
\text { Contamination }\end{array}$ & $\begin{array}{c}\text { Characteristic Clinical } \\
\text { Symptoms }\end{array}$ & Gross Pathology & $\begin{array}{l}\text { Histological } \\
\text { Findings }\end{array}$ & $\begin{array}{l}\text { Death after } \\
\text { Onset of } \\
\text { Clinical } \\
\text { Symptoms }\end{array}$ & PRV Detection & Publication \\
\hline 13 & 2014 & China & 3522 minks & $\begin{array}{l}\text { Fed raw pork } \\
\text { meat? }\end{array}$ & $\begin{array}{l}\text {-Pneumonia like } \\
\text { symptoms } \\
\text {-Diarrhea } \\
\text {-Lethargy }\end{array}$ & Not specified & Not specified & $48 \mathrm{~h}$ & $\begin{array}{l}\text { Virus isolation } \\
\text { and PCR on } \\
\text { brain and } \\
\text { internal organs } \\
\text { samples }\end{array}$ & [37] \\
\hline 14 & 2014 & China & $\begin{array}{l}1200 \text { captive } \\
\text { foxes }\end{array}$ & $\begin{array}{l}\text { Fed raw pork } \\
\text { livers }\end{array}$ & $\begin{array}{l}\text {-Initial fever } \\
\text {-Intense pruritus } \\
\text {-Frequent snarling and } \\
\text { repeated lying down and } \\
\text { rising } \\
\text {-Dyspnea } \\
\text {-Vomiting } \\
\end{array}$ & Not specified & Not specified & $12-96 \mathrm{~h}$ & $\begin{array}{l}\text { Virus isolation } \\
\text { and PCR on } \\
\text { brain samples }\end{array}$ & [38] \\
\hline 15 & 2014 & USA & $\begin{array}{l}10 \text { hunting } \\
\text { dogs }\end{array}$ & $\begin{array}{l}\text { Contact with } \\
\text { feral swine } \\
\text { while hunting } \\
\text { and } \\
\text { consumption of } \\
\text { pig offal }\end{array}$ & $\begin{array}{l}\text {-Intense pruritus with } \\
\text { self-mutilation } \\
\text {-Erythema } \\
\text {-Vomiting }\end{array}$ & Not specified & $\begin{array}{l}\text { Moderate } \\
\text { lymphoplasmatic } \\
\text { encephalitis in the } \\
\text { brainstem }\end{array}$ & $24 \mathrm{~h}$ & $\begin{array}{l}\text { IHC, virus } \\
\text { isolation and } \\
\text { PCR on brain } \\
\text { samples }\end{array}$ & [39] \\
\hline 16 & 2017 & Spain & 1 Iberian Lynx & $\begin{array}{l}\text { Eaten raw pig } \\
\text { meat or offal? }\end{array}$ & $\begin{array}{l}\text { Signs of scratching in } \\
\text { the neck with } \\
\text { self-mutilation }\end{array}$ & $\begin{array}{l}\text {-Congested } \\
\text { meninges } \\
\text {-Multifocal erosions } \\
\text { of the duodenum }\end{array}$ & $\begin{array}{l}\text {-Meningoencephalitis } \\
\text { with neutrophil and } \\
\text { mononuclear cell } \\
\text { infiltration } \\
\text {-Gastrointestinal } \\
\text { tract lesions }\end{array}$ & Found dead & $\begin{array}{l}\text { PCR and IHC on } \\
\text { brain, tonsil and } \\
\text { intestinal } \\
\text { samples }\end{array}$ & [40] \\
\hline 17 & 2017 & China & 1 wolf & $\begin{array}{l}\text { Fed pork or pig } \\
\text { offal }\end{array}$ & $\begin{array}{l}\text {-Intense pruritus } \\
\text {-Paroxysmal convulsions } \\
\text {-Quadriplegia } \\
\text {-Dyspnea } \\
\text {-Vomiting }\end{array}$ & $\begin{array}{l}\text {-Hemorrhagic spots } \\
\text { and necrosis in the } \\
\text { liver } \\
\text {-Hyperemia } \\
\text {-Hemorrhages and } \\
\text { edema in the } \\
\text { meninges }\end{array}$ & Not specified & $6 \mathrm{~h}$ & $\begin{array}{l}\text { PCR on brain, } \\
\text { tonsil and lung } \\
\text { samples }\end{array}$ & [41] \\
\hline 18 & 2017 & Serbia & 1 domestic dog & Fed pig offal & $\begin{array}{l}\text {-Pruritus in the head and } \\
\text { neck } \\
\text {-Ataxia }\end{array}$ & $\begin{array}{l}\text { Focal pulmonary, } \\
\text { gastric and renal } \\
\text { hemorrhages }\end{array}$ & Not specified & $24 \mathrm{~h}$ & $\begin{array}{l}\text { Virus isolation } \\
\text { and PCR on } \\
\text { brain and } \\
\text { internal organ } \\
\text { samples }\end{array}$ & [42] \\
\hline
\end{tabular}


Table 1. Cont

\begin{tabular}{|c|c|c|c|c|c|c|c|c|c|c|}
\hline Case $^{\circ}$ & $\begin{array}{c}\text { Year of } \\
\text { Occurrence }\end{array}$ & Country & $\begin{array}{l}\text { Species and } \\
\text { Number of } \\
\text { Confirmed } \\
\text { Cases }\end{array}$ & $\begin{array}{c}\text { Source of } \\
\text { Contamination }\end{array}$ & $\begin{array}{c}\text { Characteristic Clinical } \\
\text { Symptoms }\end{array}$ & Gross Pathology & $\begin{array}{l}\text { Histological } \\
\text { Findings }\end{array}$ & $\begin{array}{l}\text { Death after } \\
\text { Onset of } \\
\text { Clinical } \\
\text { Symptoms }\end{array}$ & PRV Detection & Publication \\
\hline 19 & 2017 & China & $\begin{array}{l}1 \text { human } \\
\text { (female) }\end{array}$ & $\begin{array}{l}\text { Eye } \\
\text { contamination } \\
\text { of pig sewage }\end{array}$ & $\begin{array}{l}\text {-Fever } \\
\text {-Headache } \\
\text {-Visual impairment } \\
\text { => Diagnosed with } \\
\text { endophthalmitis } \\
\text { => Under antiviral } \\
\text { therapy } \\
\text { (acyclovir) }\end{array}$ & Not applicable & Not applicable & $\begin{array}{l}\text { The patient } \\
\text { survived }\end{array}$ & $\begin{array}{l}\text { NGS, Sanger } \\
\text { sequencing and } \\
\text { PCR on vitreous } \\
\text { humor samples } \\
\text {-PRV antibody } \\
\text { test positive in } \\
\text { CSF, } 4 \text { months } \\
\text { after disease } \\
\text { onset }\end{array}$ & [10] \\
\hline 20 & 2018 & Argentina & 1 domestic dog & $\begin{array}{l}\text {-Exposure to a } \\
\text { serologically } \\
\text { positive swine } \\
\text { farm } \\
\text {-Direct contact } \\
\text { with pigs or fed } \\
\text { raw pork meat } \\
\end{array}$ & $\begin{array}{l}\text {-Pruritus } \\
\text {-Tremors } \\
\text {-Trismus } \\
\text {-Spasms of muscles of the } \\
\text { larynx and pharynx } \\
\text {-Dyspnea } \\
\text {-Vomiting }\end{array}$ & Not specified & $\begin{array}{l}\text {-Mononuclear cell } \\
\text { infiltration in } \\
\text { meninges } \\
\text {-Mild diffuse gliosis } \\
\text {-Neuronal satellitosis } \\
\text { in gray matter }\end{array}$ & $24-48 \mathrm{~h}$ & $\begin{array}{l}\text { Virus isolation } \\
\text { and PCR on } \\
\text { brain samples }\end{array}$ & [43] \\
\hline 21 & 2018 & China & 9 cattle & $\begin{array}{l}\text { Close contact to } \\
\text { pig house }\end{array}$ & $\begin{array}{l}\text {-Banging their head to } \\
\text { the walls (scratching) } \\
\text {-Ataxia } \\
\text {-Gait and salivation }\end{array}$ & $\begin{array}{l}\text { Leptomeningeal } \\
\text { hyperaermia }\end{array}$ & $\begin{array}{l}\text {-Non suppurative } \\
\text { meningoencephalitis } \\
\text { with mononuclear } \\
\text { perivascular cuffing } \\
\text {-Neuronal necrosis } \\
\text {-Satellitosis }\end{array}$ & $24 \mathrm{~h}$ & $\begin{array}{l}\text { PCR on brain } \\
\text { samples }\end{array}$ & [44] \\
\hline 22 & 2018 & China & 1 human (male) & $\begin{array}{l}\text { Veterinarian, } \\
\text { hands } \\
\text { punctured by a } \\
\text { knife used } \\
\text { during autopsy } \\
\text { of dead swine }\end{array}$ & $\begin{array}{l}\text {-Fever } \\
\text {-Headaches } \\
\text {-Seizures } \\
\text {-Coma within } 3 \text { days after } \\
\text { the appearance of } \\
\text { symptoms } \\
\text {-Lumbar puncture } \\
\text { indicated an opening } \\
\text { pressure } \\
\text {-CT brain imaging } \\
\text { showed hypodensity in } \\
\text { the bilateral basal ganglia } \\
\text { => Diagnosed with viral } \\
\text { encephalitis } \\
\text { => Under antiviral } \\
\text { therapy for } 2 \text { weeks } \\
\text { (acyclovir) }\end{array}$ & Not applicable & Not applicable & $\begin{array}{l}\text { The patient } \\
\text { survived }\end{array}$ & $\begin{array}{l}\text { PRV gB (serum } \\
\text { and CSF) and gE } \\
\text { (serum) } \\
\text { antibodies } \\
\text { detected at day } \\
21 \text { and } 28 \text { after } \\
\text { disease onset }\end{array}$ & [45] \\
\hline
\end{tabular}


Table 1. Cont

\begin{tabular}{|c|c|c|c|c|c|c|c|c|c|c|}
\hline Case $^{\circ}$ & $\begin{array}{c}\text { Year of } \\
\text { Occurrence }\end{array}$ & Country & $\begin{array}{l}\text { Species and } \\
\text { Number of } \\
\text { Confirmed } \\
\text { Cases }\end{array}$ & $\begin{array}{c}\text { Source of } \\
\text { Contamination }\end{array}$ & $\begin{array}{c}\text { Characteristic Clinical } \\
\text { Symptoms }\end{array}$ & Gross Pathology & $\begin{array}{l}\text { Histological } \\
\text { Findings }\end{array}$ & $\begin{array}{l}\text { Death after } \\
\text { Onset of } \\
\text { Clinical } \\
\text { Symptoms }\end{array}$ & PRV Detection & Publication \\
\hline 23 & 2018 & China & $\begin{array}{c}5 \text { humans (4 } \\
\text { males and } 1 \\
\text { female) }\end{array}$ & $\begin{array}{l}\text {-Contact with } \\
\text { pigs at } \\
\text { slaughterhouse } \\
\text {-Hand injury at } \\
\text { work }\end{array}$ & $\begin{array}{l}\text {-Fever } \\
\text {-Seizures } \\
\text {-Respiratory failure } \\
\text {-Visual impairment } \\
\text {-Retinal necrosis } \\
\text {-Brain MRI showed } \\
\text { abnormal signs in the } \\
\text { temporal lobes and } \\
\text { insular cortex } \\
\text { => All diagnosed with } \\
\text { viral encephalitis } \\
\text { => Under antiviral } \\
\text { therapy (not specified) }\end{array}$ & Not applicable & Not applicable & $\begin{array}{l}\text { All patients } \\
\text { survived }\end{array}$ & $\begin{array}{l}\text { NGS in CSF } \\
\text { (2 to } 37 \text { PRV } \\
\text { reads detected) }\end{array}$ & [46] \\
\hline 24 & 2019 & China & 1 human (male) & $\begin{array}{l}\text { Contact with } \\
\text { pigs at work } \\
\text { (sick pig } \\
\text { handler) }\end{array}$ & $\begin{array}{l}\text {-Fever } \\
\text {-Convulsions } \\
\text {-Pulmonary } \\
\text { inflammation } \\
\text {-Visual impairment } \\
\text {-Retinal necrosis } \\
\text {-Brain MRI showed } \\
\text { hypo-intensity in the } \\
\text { bilateral temporal lobe } \\
\text { and hippocampus } \\
\text { => Diagnosed with } \\
\text { encephalitis complicated } \\
\text { with bilateral retinal } \\
\text { necrosis } \\
\text { => Under antiviral } \\
\text { therapy } \\
\text { (acyclovir) }\end{array}$ & Not applicable & Not applicable & $\begin{array}{l}\text { The patient } \\
\text { survived }\end{array}$ & $\begin{array}{l}\text { NGS in CSF (72 } \\
\text { PRV reads } \\
\text { detected) }\end{array}$ & [47] \\
\hline
\end{tabular}


Table 1. Cont

\begin{tabular}{|c|c|c|c|c|c|c|c|c|c|c|}
\hline Case $n^{\circ}$ & $\begin{array}{l}\text { Year of } \\
\text { Occurrence }\end{array}$ & Country & $\begin{array}{c}\text { Species and } \\
\text { Number of } \\
\text { Confirmed } \\
\text { Cases }\end{array}$ & $\begin{array}{c}\text { Source of } \\
\text { Contamination }\end{array}$ & $\begin{array}{c}\text { Characteristic Clinical } \\
\text { Symptoms }\end{array}$ & Gross Pathology & $\begin{array}{l}\text { Histological } \\
\text { Findings }\end{array}$ & $\begin{array}{l}\text { Death after } \\
\text { Onset of } \\
\text { Clinical } \\
\text { Symptoms }\end{array}$ & PRV Detection & Publication \\
\hline 25 & 2020 & China & 1 human (male) & $\begin{array}{l}\text {-Contact with } \\
\text { pigs (pork } \\
\text { vendor) } \\
\text {-Hand cut }\end{array}$ & $\begin{array}{l}\text {-Fever } \\
\text {-Seizures } \\
\text {-Coma within } 1 \text { day after } \\
\text { the appearance of } \\
\text { symptoms } \\
\text {-Brain MRI showed } \\
\text { abnormal signals in the } \\
\text { bilateral frontal lobe, } \\
\text { temporal lobe, insula } \\
\text { lobe, basal ganglia and } \\
\text { hippocampus } \\
\text {-Inflammatory lesions in } \\
\text { the bilateral hemisphere } \\
\text { =>Diagnosed with viral } \\
\text { encephalitis } \\
\text { =>Under antiviral } \\
\text { therapy for } 2 \text { weeks } \\
\text { (acyclovir) }\end{array}$ & Not applicable & Not applicable & $\begin{array}{l}\text { The patient } \\
\text { survived }\end{array}$ & $\begin{array}{l}\text { - NGS in CSF (74 } \\
\text { reads detected) } \\
\text {-PRV antibodies } \\
\text { detected in } \\
\text { plasma and CSF } \\
\text { at } 23 \text { and } 56 \\
\text { days after } \\
\text { disease onset }\end{array}$ & [48] \\
\hline 26 & 2018 & China & $\begin{array}{c}4 \text { humans } \\
(3 \text { male and } 1 \\
\text { female) }\end{array}$ & $\begin{array}{l}\text {-Exposed to raw } \\
\text { pork at work } \\
-1 \text { injured during } \\
\text { pork cutting }\end{array}$ & $\begin{array}{l}\text {-Fever } \\
\text {-Seizures } \\
\text {-Coma within } 1 \text { to } 4 \text { days } \\
\text {-Respiratory failure } \\
\text {-Brain MRI showed } \\
\text { abnormal signals mainly } \\
\text { in the bilateral areas of } \\
\text { the temporal lobe and } \\
\text { bilateral basal ganglia } \\
\text {-2/4=> Bilateral retinitis } \\
=>\text { All diagnosed with } \\
\text { viral encephalitis } \\
=>\text { Under antiviral } \\
\text { therapy for } 2 \text { weeks } \\
\text { (acyclovir) }\end{array}$ & Not applicable & Not applicable & $\begin{array}{c}\text { Three } \\
\text { patients } \\
\text { survived and } \\
1 \text { died }\end{array}$ & $\begin{array}{l}\text {-NGS in CSF } \\
\text {-PRV antibodies } \\
\text { detected in } \\
\text { available serum } \\
\text { of } 3 \text { patients }\end{array}$ & [9] \\
\hline
\end{tabular}

Central nervous system (CNS); Trigeminal ganglia (TG); Cerebrospinal fluid (CSF); Immunohistochemistry (IHC); Immunofluorescence (IF); Hematoxylin and eosin (H\&E); Next generation sequencing (NGS); electron microscopy (EM); Polymerase chain reaction (PCR). 


\section{The Pathogenesis of PRV}

Here, we compare the main steps in the pathogenesis of PRV between its natural host, the swine, and non-natural hosts that may inform the mechanisms governing PRV-induced neuropathic itch.

\subsection{Introduction}

PRV is a highly contagious pathogen that causes respiratory disease, neurological disorders, and abortion in swine. Transmission occurs primarily through direct contact with oral and nasal secretions, but can also occur by aerosols, transplacentally or venerally [49-51]. Other animal species are commonly infected through direct contact with pigs or through the consumption of raw offal from infected pigs (See Table 1). The infected animals develop a severe pruritus and usually die within 2 days.

\subsection{Primary Replication in the Upper Respiratory Tract (URT)}

Upon entry into the natural host, PRV first forms foci of infection in the epithelial cells lining the URT, including nasal septum, tonsils, nasopharynx, trachea and lungs [14,52-54] (Figure 1(1a)). Ex vivo experiments showed that PRV-induced foci can be detected in the epithelium of swine nasal mucosa explants starting after 24 hpi $[55,56]$. Primary PRV infection of several tissues of the swine URT results in the destruction and erosion of the epithelium, causing mild respiratory symptoms, such as sneezing, coughing, dyspnea, and nasal discharge. These symptoms appear after 3 to 6 days and can last up to 10 days [51]. However, infected swine usually recover quickly, except for those who develop pneumonia due to secondary bacterial infections [57]. Viral shedding can be detected in nasal secretions from 1 to 14 days post-inoculation (dpi) [14,58] (Figure 1(1b)).

The entry of PRV into non-natural hosts has not been well studied but the presence, in most cases, of a pruritus in the head and neck dermatome, suggests that infectious virus particles mainly enter the body in natural conditions via the upper respiratory tract, including the nose, mouth, sinus, larynx and trachea (See Table 1 and Figure 2(1)). Experimental infection of mice via the intranasal route demonstrated PRV-positive cells in the respiratory epithelium at 6 and 24 hpi by immunofluorescence staining [7,59]. After intranasal inoculation, PRV was found in the nasal secretions of cattle and could be isolated from the nasal and pharyngeal mucosa and tonsils of infected animals [53] (Figure 2(1a)). Non-natural hosts can also shed PRV from nasal secretions, but only for a short time as the infected animals die very quickly (Figure 2(1b)). PRV also can replicate in the skin of mice after skin flank and footpad inoculations. Infectious virus was detected in the footpad around 18-24 hpi and in the skin of the flank area at 36 hpi [60-62].

\subsection{PRV Entry into the Peripheral Nervous Ssystem (PNS) Neurons and Spread to the Central Nervous System (CNS)}

After primary replication in the nasal epithelium of adult swine as described in 4.2, PRV enters nerve endings of the PNS, including those coming from the sensory TG and olfactory bulb as well as other facial, parasympathetic, sympathetic nerve neurons that innervate the nasal mucosa [59] (Figure 1(1e)). Virions travel via retrograde transport to the sensory and autonomic peripheral ganglia. A hallmark of herpesviruses is the establishment of a reactivable, latent infection in their hosts [63]. Accordingly, PRV establishes a lifelong latent infection in swine PNS neurons [64,65] (Figure 1(2)). Meanwhile, the infected pigs recover from the respiratory disease and become asymptomatic $[58,66]$. Upon stress-induced reactivation, viral replication occurs in the PNS ganglia, and virions spread in the anterograde direction along the nerves to the mucosal surfaces where the infection started [67]. Adult swine may exhibit mild respiratory signs upon viral reactivation. PRV rarely spreads in the retrograde direction to reach the CNS to cause encephalitis in adult swine. Cycles of latency and reactivation in pigs result in shedding of infectious virus and transmission to uninfected animals, facilitating the viral reservoir in herds. Interestingly, other human and animal herpesviruses, such as VZV and bovine herpesvirus type 1 (BHV-1) have been shown to invade PNS neurons in a similar way [68,69]. 
In non-natural hosts, PRV similarly enters nerve endings of the PNS that innervate the nasal mucosa and initiates a productive infection in PNS neurons (Figure 2(1c,2)). Infectious virus and DNA have been recovered from TG of naturally infected mink and dogs [28,30,32] (Figure 2(2a)). PRV particles were also found by electron microscopy in satellite glia cells and PNS neurons of autonomic ganglia from infected dogs after subcutaneous and intramuscular inoculations [70]. In contrast, a previous study from Fields and Hills described the absence of enveloped virions within satellite glia cells of lumbar dorsal root ganglia (DRG) after footpad inoculation, suggesting that an abortive infection occurred in these cells [62]. It remains unclear if PRV can productively infect satellite glia cells via transfer of virus particles from infected neurons. Following intranasal inoculation, PRV antigens were detected in the ipsilateral TG of mice at 3 dpi [59,71]. In dogs, PRV antigens were detected in stellate, celiac and caudal mesenteric ganglion at 4 dpi after subcutaneous inoculation [33]. Experimental inoculation of mice through the footpad and skin flank demonstrated the presence of infectious virus in the ipsilateral DRG starting from 42 and $36 \mathrm{hpi}$, respectively [61,62]. The presence of infectious virus suggests active viral replication in PNS neurons, which coincides with the start of pruritus in infected animals. As non-natural hosts die very quickly after PRV infection, it is not clear whether the virus is able to establish latency in PNS neurons. A study from Osorio and colleagues reported successful establishment of PRV latency in TG after passive immunization of mice prior to inoculation with an attenuated PRV strain (PRV-Bartha) [66]. The authors could recover infectious virus from TG explants and detected PRV DNA in latently infected TG in mice by PCR and in situ hybridization after 2 to 8 months post-inoculation. As of now, no studies have demonstrated the establishment of latency in non-natural hosts following inoculation with a virulent PRV strain that causes pruritus.

After replication in the PNS, progeny virions may spread in the retrograde direction from the PNS to the CNS if the animals survive long enough. Infectious virus and viral DNA have been recovered from brain samples of many naturally infected animals (See Table 1 and Figure 2(2b)). PRV replication in the brain causes encephalitis. After intranasal inoculation, the virus was detected in the mouse brainstem at 3 dpi [71]. In addition, infectious PRV was detected in the brainstem of infected mice around 66-72 hpi following skin flank and footpad inoculations [61,62]. PRV DNA was also detected in the spinal cord and hindbrain of infected mice at $82 \mathrm{hpi}$ (moribund state) following footpad inoculation. Interestingly, the midbrain and forebrain were rarely found positive for viral antigens, probably due to the short survival of the animals. These findings suggested that extensive viral replication in the brain is not responsible for the acute death of the infected animals.

\subsection{PRV Replication in the Draining Lymph Nodes and Viremia}

Following replication in the swine respiratory epithelium, PRV may cross the basement membrane $(\mathrm{BM})$ in foci to penetrate the connective tissues and reach the draining lymph nodes and bloodstream [56,72] (Figure 1(1c,d)). The invasion of PRV through the BM towards the lamina propria is mediated by trypsin-like serine protease activity [73]. Within $24-48 \mathrm{hpi}$, infectious virus as well as viral antigens can be detected in swine inguinal lymph nodes [74-76]. Virus can persist in pharyngeal lymph nodes for up to 35 days [77]. PRV infection is amplified in the draining lymph nodes with discharge of infected leukocytes, via the efferent lymph, into the blood circulation. As a result, PRV initiates a cell-associated viremia in peripheral blood mononuclear cells of swine (mainly monocytes) that facilitates dissemination within the host (Figure 1(3)). Cell-free viremia can also occur in infected pigs $[78,79]$. Viremia can be detected after $1 \mathrm{dpi}$ and persists for 2 weeks. The cell-associated viremia is a prerequisite for the dissemination of PRV to the pregnant uterus.

There are only a few studies that confirmed the presence of infectious PRV in lymph nodes of non-natural hosts following experimental infections. In cattle, PRV could be isolated from the retropharyngeal lymph nodes following intranasal inoculation [53]. Virus was also detected in the pituitary, pharynx and submaxillary lymph nodes of cattle after oral infection [80]. However, PRV was not detected in the lymph nodes of experimentally and naturally infected dogs [30,33]. So far, no 
evidence exists for cell-free or cell-associated viremia in non-natural hosts. No infectious virus was detected in tissues other than the nervous system of infected dogs and mice $[30,33,81]$. In addition, intravenous inoculation of cattle with PRV failed to disseminate the virus throughout the body. Consequently, these results suggested that a viremia is unlikely to occur in non-natural hosts.

\subsection{Secondary Replication in the Swine Pregnant Vterus}

Once in the blood circulation, infected monocytes adhere to and subsequently transfer PRV to the endothelial cells (EC) lining the blood vessels of the placenta (Figure 1(4)). Secondary replication in the placenta can cause vasculitis and multifocal thrombosis, resulting in abortion [82-84]. The infection of EC is mediated by cell-to-cell contacts between infected monocytes and EC [85]. The development of abortion may depend on the hormonal activity and immune status of sows during pregnancy. Indeed, it was demonstrated that the expression of adhesion molecules on EC is induced by cytokines and hormones present in the local environment during pregnancy [86-88]. These cytokines may facilitate the adhesion of infected monocytes to the endothelium.

After intranasal, intra-uterine, and intra-fetal inoculations of vaccinated pregnant sows, PRV antigen can be detected in vaginal and sacral ganglia [89]. A widespread EC infection may cause detachment of the fetal membranes during the first trimester of gestation, thus leading to the abortion of a virus-negative fetus or cause fetal reabsorption in swine. Less extensive uterine vascular pathology may allow for transplacental infection and lead to the abortion of a virus-positive fetus during the second and third trimester of gestation or stillborn pig [51,90]. Viral aborted fetuses usually show multiple lesions, including foci of necrosis in the liver, spleen and lungs. PRV can be isolated from the liver, spleen, lungs, body fluids, and brain from fetuses aborted from vaccinated pregnant sows $[82,91]$.

At this time, no cases of abortion have been described in pregnant cows, dogs or other non-natural hosts after PRV infection. After primary replication in the nasal epithelium, a secondary replication of PRV in the placenta of these animals is unlikely due to the absence of a cell-associated viremia.

\subsection{PRV Infection in Suckling and Weaned Piglets}

PRV infection is more severe in piglets than in adult swine [53]. In neonates, sudden death usually occurs with few to no clinical signs. In suckling pigs, death is preceded by fever, vomiting and CNS signs such as problems of coordination, weakness of the hindquarters, convulsions and paralysis. Mortality in neonates and suckling pigs is close to $100 \%$. In weaner pigs, clinical signs resemble those in suckling pigs with the involvement of respiratory signs including dyspnea, sneezing, coughing, and nasal discharge. Mortality rate is around $5-10 \%$. No marked pruritus develops in pigs of any age. Infectious virus could be detected in brain samples of four piglets naturally infected with PRV [92]. The severity of the symptoms decreases with age and has been correlated to a more effective immunity in adult swine compared to that of piglets. 
1. Primary replication in the respiratory tract

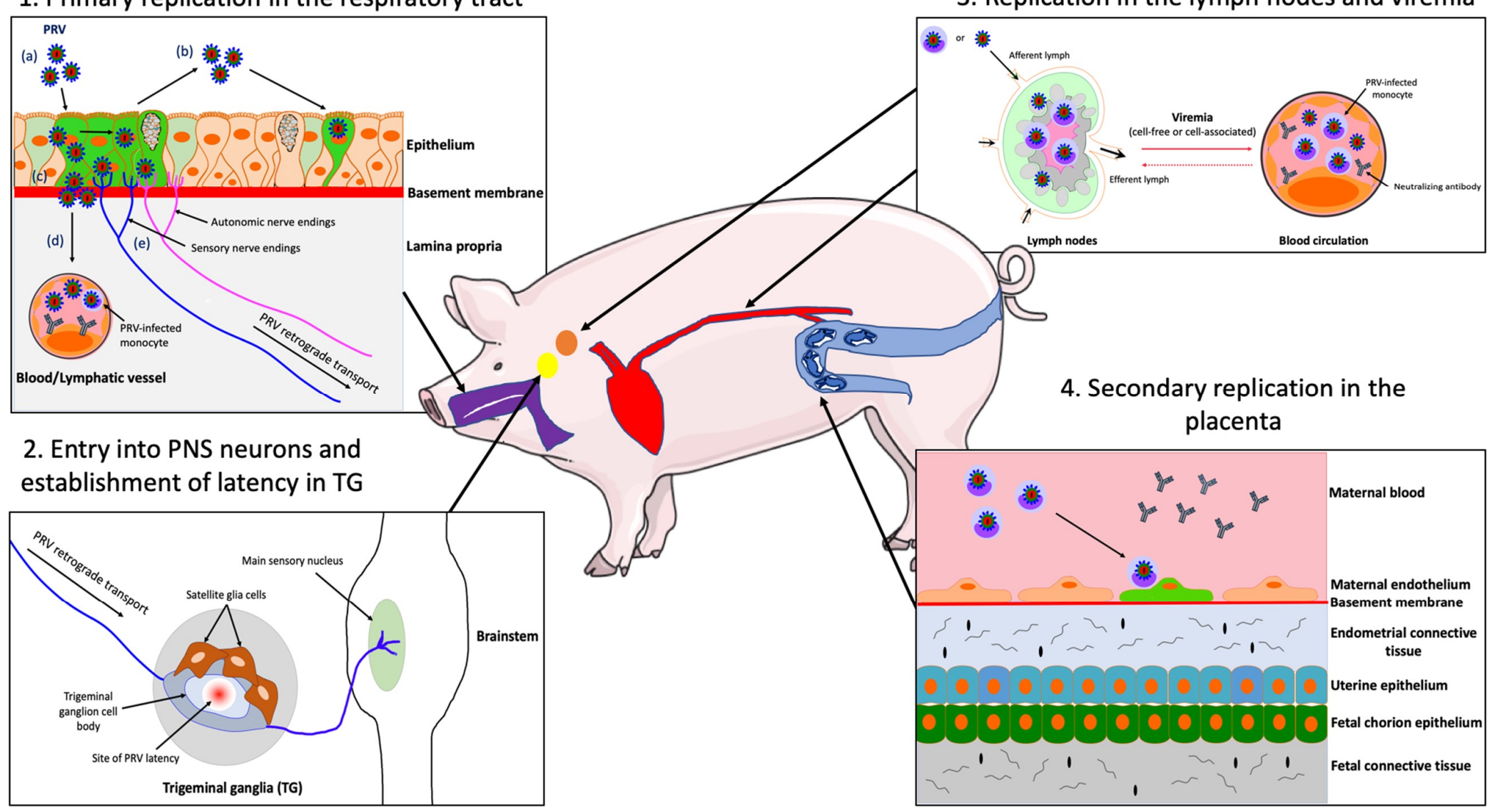

Figure 1. Schematic representation of the pathogenesis of PRV in the adult pig. (1) PRV first replicates in the epithelial cells of the URT; (a) PRV infection; (b) viral spread within the respiratory epithelium and viral shedding; (c) PRV breaches the basement membrane via protease activity and penetrates the lamina propria; (d) PRV reaches the draining lymph nodes and blood circulation; (e) PRV enters nerve endings of the PNS, including those coming from the trigeminal ganglia (TG) and spreads in the retrograde direction to the ganglia. (2) PRV establishes latency in TG neurons. (3) PRV replicates in the draining lymph nodes and establishes a cell-free and/or cell-associated viremia in PBMCs (mainly monocytes). (4) Via a cell-associated viremia in monocytes, PRV is transported to the placenta where it initiates a secondary replication in the endothelial cells lining the blood vessels of this organ. Purple = respiratory tract; red = blood circulation; orange = lymph nodes; yellow $=$ TG; blue $=$ uterus. 
1. Primary replication in the respiratory tract

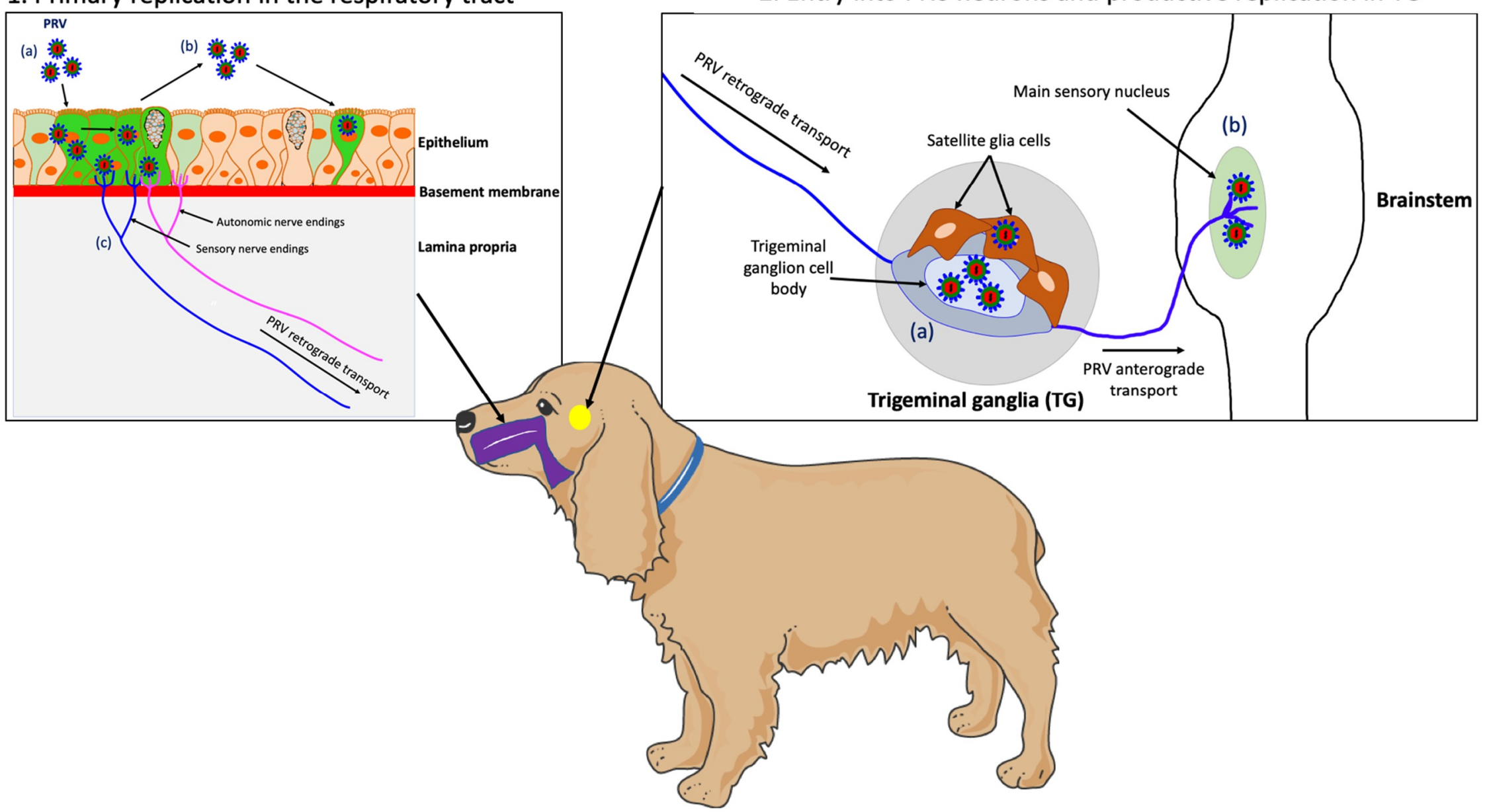

Figure 2. Schematic representation of the pathogenesis of PRV in a non-natural host, the dog. (1) PRV first replicates in the epithelium of the URT; (a) PRV infection; (b) viral spread within the respiratory epithelium and viral shedding; (c) PRV enters nerve endings of the PNS, including those coming from the TG and spreads in the retrograde direction to the ganglia. (2) PRV initiates a productive infection in TG neurons; (a) PRV replicates in cell bodies of TG neurons; (b) New progeny virions can further spread in the anterograde direction and infect the CNS (brainstem). Purple = respiratory tract; yellow = TG. 


\section{The Pathogenesis of PRV-Induced Neuropathic Itch}

In this section, we will briefly introduce the definition and clinical classification of itch and further dissect the neuronal and immunological basics for the unstoppable itch sensation in PRV-infected animals.

\subsection{Clinical Classification of Itch}

Itch, also known as a pruritus, was defined in 1660 by a German physician Samuel Hafenreffler as an "unpleasant sensation that elicits the desire or reflex to scratch". Pruritus can be acute or chronic $[93,94]$. Acute itch can be triggered by insect bites and relieved by scratching. Scratching, in turn, generates a mild pain that inhibits the itch sensation. In contrast, chronic itch can last for a longer period of time ( $>6$ weeks duration) and scratching usually does not relieve the itch $[95,96]$.

A clinical classification of chronic itch has been proposed by the International Forum for the Study of Itch and comprised 4 categories: the pruriceptive itch, the neurogenic itch, the neuropathic itch and the psychogenic itch (IFSI; http://www.itchforum.net). The first category is the pruriceptive itch that is caused by inflammatory skin disorders, such as atopic dermatitis, psoriasis, drug reactions, mites, and uticaria [97]. Pruriceptive itch originates following activation of primary afferent nerve terminals located in the skin. The main pruritogens, or itch-producing stimuli are histamine, interleukins, prostanglandins, and proteases. The second category is the neurogenic itch that results from CNS activation without necessary activation of sensory nerve fibers and is usually accompanied by visceral diseases such as chronic liver disease and chronic renal failure [98]. The third category is the neuropathic itch, a chronic condition that arises from viral-induced disease and/or traumatic nerve injury of the PNS or CNS, such as peripheral neuropathies (e.g., post-herpetic itch), multiple sclerosis and nerve compression or irritation (e.g., notalgia paresthethica, and brachoradial pruritus [99]. The main mediators of the neuropathic itch are neuropeptides, proteases and inflammatory mediators such as cytokines. Finally, the fourth category is the psychogenic itch related to psychological or psychiatric disorders, such as itch associated with delusions of parasitosis, stress and depression [100].

\subsection{The Neuropathic Itch}

Neuropathic itch (NI) is defined as perception of itch in the absence of pruritogenic stimuli [101]. NI can originate at any point along the sensory afferent pathway as a result of damage of the PNS and less frequently of the CNS. These PNS lesions occurs in sensory itch neurons including slow conducting myelinated $(\mathrm{A} \delta$ ) and unmyelinated (C) nerve fibers [102]. In contrast, lesions that affect motor neurons are not associated with NI. NI are often characterized depending on the location of the nerve damage. For instance, brachioradial pruritus and notalgia paresthetica are focal NI, caused by damage of small fibers within cervical spinal nerves and damage to the cutaneous branches of the posterior divisions of the spinal nerves, respectively [103]. The most common focal NI arising from sensory ganglia lesions occurs during VZV reactivation within sensory ganglia, initially presenting as the zosteriform lesion known as shingles. In contrast, polyneuropathies arise from generalized peripheral nerve damage [104]. Finally, NI syndromes can also arise from lesions within the spinal cord (e.g., multiple sclerosis) and in the brain (stroke) [105-107]. In the brain, any types of lesions that damage itch circuitry can cause NI.

The mechanisms underlying the neuropathic itch are still poorly understood and data are scarce. The main consensus is that peripheral nerve injury activates PNS sensory itch neurons to fire excessively and thus, stimulate excitative interneurons in the dorsal horn of the spinal cord to release gastrin-releasing peptide (GRP). Then, the release of this neuropeptide further stimulates spinothalamic tract (STT) neurons that send itch signals to the thalamus $[108,109]$. Finally, these signals are relayed and processed in the somatosensory cortex. The central inhibition of itch pathway neurons in the brain that should be in turn activated, is likely dampened or disabled, resulting in an unstoppable itch sensation [110].

\subsection{The Neuronal Mechanisms of PRV-Induced Neuropathic Itch}

Based on studies of the pathogenesis of PRV in non-natural hosts (see Section 4.3), continuous PRV replication in PNS ganglia causes neuronal lesions that are likely responsible for the initiation of 
the pruritus in these animals. Several animal models have been used to further dissect the mechanisms by which PRV replication in PNS neurons cause pruritus.

A study from Dempsher and colleagues first demonstrated that PRV induces spontaneous, intermittent discharge of nerve impulses over the preganglionic and postganglionic nerves of superior cervical ganglia following ocular inoculation. The spontaneous discharges were only found in PRV-infected sympathetic ganglia of rats showing pruritus [111]. Similar results were observed after intraocular and intradermal PRV inoculations in rats [112-114]. Interestingly, inoculation with a PRV pruritus-producing strain (L strain) induced spontaneous hyperexcitability of neurons. In contrast, the non-pruritus producing strain (G strain), known to cause meningoencephalitis, exhibited impaired sympathetic synaptic conduction in infected rats [112]. Voltage-gated sodium and calcium channels were found to be responsible for the initiation and propagation of action potential (AP) in the infected ganglia [114].

In addition, PRV infection induces electrical coupling and increases AP firing rates in cultured rat sympathetic neurons in vitro [115]. The formation of fusion pores between infected PNS neurons was found to be mediated by PRV $\mathrm{gB}$. PRV $\mathrm{gB}$ protein is an important component of the viral membrane fusion complex (gB/gH/gL) and is crucial for viral entry into neurons [116]. The production of fusion pores facilitates the flow of ions between PNS neurons and causes direct electrical coupling [115]. Moreover, it was demonstrated that infection of PNS neurons of the submandibular ganglia with a virulent PRV pruritus-producing strain (PRV-Becker) induces synchronous and cyclical activity in neuronal cell bodies [117]. Also, it was found that newly made virus particles in infected neurons were transported in axons back to the glands where the infection started. Thus, the authors introduced the concept of "round-trip" reseeding and amplification of the infection in the ganglia. The ability to reseed the gland increases the infection of the innervating ganglia and the involvement of more axons in electrical firing, therefore directly contributing to the pruritus. In contrast, mice infected with an attenuated, live vaccine and non-pruritus producing strain (PRV-Bartha) did not show signs of synchronous and cyclical activity in infected ganglia. This difference was attributed to the fact that PRV-Bartha lacks the US9 protein required for sorting virion proteins into axons [118]. Recent results are in agreement with the PRV round-trip concept. For instance, a large amount of infectious virus was detected in the mouse footpad at moribund state after footpad inoculation. Likely, it resulted from virus particles that originally infected the DRG, replicated and went back to the footpad rather than from local viral replication in the footpad. Indeed, the inoculated footpad, which exhibited epidermal necrosis accompanied by immune cell infiltrates, did not have time to regenerate and support efficient viral replication [81].

Finally, a comparative study of the neuroinvasive mechanisms between virulent PRV-Becker and attenuated PRV-Bartha was performed using the mouse flank inoculation model. In contrast to PRV-Becker infection, mice infected with PRV-Bartha did not develop pruritus and lived twice as long. However, they did show severe CNS symptoms due to widespread PRV-Bartha infection in the brain and eventually died of viral encephalitis. Using several PRV mutants, the authors demonstrated that the pruritus stimulus was mainly mediated by US9, gE and gI proteins [61]. These 3 gene products, which are deleted in the PRV-Bartha strain, are required for virulence and efficient anterograde spread of PRV within the nervous system [118-120].

\subsection{The Immune Mechanisms of PRV-Induced Neuropathic Itch}

The immune system plays a crucial role in the development of neuropathic itch. In the case of a pruriceptive itch, skin inflammation results in the recruitment and activation of immune cells to the skin epithelium. Activated immune cells release pro-inflammatory mediators, such as interleukin (IL) 31 and IL-33 that sensitize pruriceptors, leading to peripheral sensitization and activation of itch signaling pathways [121]. In the case of a neuropathic itch, peripheral nerve injury can cause inflammation of the nervous system, so called neuroinflammation. The PNS and CNS neurons as well as resident satellite glia, microglia, and astrocytes can also produce inflammatory mediators, including pro-inflammatory cytokines and chemokines, neuropeptides and reactive oxygen species. The release of neuropeptides such as substance P and calcitonin gene-related peptide (CGRP) by 
activated primary sensory neurons has been shown to have paracrine effects on immune cells and can increase the inflammation and subsequently amplify the itch sensation [122,123]. The same localized immune activation can be mimicked after viral infection of PNS neurons. For instance, reactivation of VZV from sensory ganglia causes a self-limited dermatomal rash with pain and itching, which is accompanied by inflammation of the skin [124].

Several cases of PRV-induced neuropathic itch reported mild purulent ganglioneuritis and encephalomyelitis in non-natural hosts, thus suggesting that PRV infection of sensory ganglia is accompanied by a specific inflammatory response (See Table 1). Indeed, perivascular cuffing of lymphocytes, monocytes and macrophages as well as a neutrophilic cell infiltration were detected in PRV-infected ganglia. So far, only a few studies investigated the role of the inflammatory response in the initiation and development of PRV-induced neuropathic itch. By the use of the mouse flank inoculation model, PRV-Becker infected mice, that were anesthetized at the time the pruritus started, did not develop skin lesions. Still, these mice died as the same time as the non-anesthetized ones. These results suggested that self-mutilation and scratching alone were not the cause of death. The authors then mentioned that a peripheral host immune response to PRV infection of the PNS could be an important factor in the death of the infected animals [61]. Using the footpad inoculation model, it was later shown that virulent PRV-Becker, but not attenuated PRV-Bartha, infection induces a specific and lethal systemic inflammatory response in mice. High levels of IL-6 and granulocyte colony-stimulating factor (G-CSF) were measured in both tissues and plasma of infected animals, including the footpad and DRG at moribund stage [81]. Furthermore, a strong correlation was found between the level of infectious virus detected in the DRG and footpad and the production of pro-inflammatory cytokines. Indeed, PRV-Becker replicated to a higher level in both tissues than PRV-Bartha. The fact that PRV-Becker was able to reseed new progeny virions back from the DRG neurons to the footpad might also have contributed to the amplification of the inflammatory response. Figure 3 shows a model of PRV-induced neuropathic itch in non-natural hosts.

Both IL-6 and G-CSF are produced by immune cells (neutrophils, T lymphocytes and macrophages) and neurons. While IL-6 has pleiotropic effects on immune response, inflammation, hematopoiesis and neurogenesis, G-CSF is mainly a key regulator of neutrophil function, mainly influencing the migration of neutrophils across the vascular endothelium [125-127]. Taken together, the high concentrations of G-CSF and IL-6 detected in the infected footpad and DRG of experimentally infected mice are likely to correlate with histological findings from naturally infected animals where a massive neutrophilic infiltration is observed in the PRV-infected ganglia. Furthermore, neutrophils can induce neurotoxicity on DRG neurons and are considered responsible for hypersensitivity and neuropathic pain observed after peripheral nerve injury [128]. Therefore, their accumulation around the infected ganglia may further amplify the neuroinflammation.

The early events of the neuroinflammatory response of PRV infection in mice were recently characterized. Using the mouse footpad inoculation model, it was demonstrated that PRV-Becker infection primes DRG neurons to a state of inflammation very early post-infection [60]. More specifically, the authors found that the peak of IL-6 and G-CSF production detected in the DRGs and footpad of infected mice at $7 \mathrm{hpi}$ could not be attributed to the infiltration of neutrophils in these tissues that occurred at $82 \mathrm{hpi}$. An efficient replication of PRV-Becker and subsequent spread in the footpad were necessary to activate DRG neurons to produce G-CSF at a very early time pi. Moreover, PRV replication was limited in the footpad of Toll-like receptor 2 (TLR2) knockout (KO) mice with no viral replication detected in DRG neurons. TLRs are expressed in nociceptive neurons and play a crucial role in neuroinflammation $[129,130]$. In particular, TLR2 is responsible for the activation of spinal cord glial cell after nerve injury and subsequent pain hypersensitivity [131]. Thus, the results suggested that TLR2 might be a potential receptor for PRV on DRG neurons, thus facilitating viral spread and the initiation of the neuroinflammatory response in mice. PRV gB expressed on new progeny virions or infected epidermal cells was proposed as a potential candidate to interact with TLR2 expressed on axon terminals of DRG neurons that are innervating the footpad. 


\subsection{Why PRV-Infected Swine Do Not Itch}

As described in Section 4, the pathogenesis of PRV is very different between its natural host, the pig, and other mammals. One first essential difference is the establishment of latency in PNS neurons of pigs followed by sporadic periods of reactivation. In contrast, PRV productively replicates in PNS neurons of non-natural hosts following primary infection of the URT and the infection can spread further to the CNS. A latent infection is not established. The second main difference is that productive PRV infection of PNS neurons triggers a specific inflammatory response that contributes to the initiation and development of the pruritus in non-natural hosts.

Using compartmented rat neuronal cultures, it was demonstrated that efficient PRV retrograde transport in axons depends on the number of virus particles infecting axons. A threshold for the number of infecting particles in axons is set for establishing a quiescent (below a MOI of 0.1 ) or productive (above a MOI of 0.1) infection in rodent PNS neurons [132]. A similar threshold of PRV infection may exist in pigs. Better immune control of the infection at the primary site, the URT, may limit the number of PRV particles reaching the cell bodies of swine PNS neurons facilitating the latent infection.

Interestingly, type I IFN suppresses PRV production replication in porcine TG neurons and porcine epithelial cells in vitro [133,134]. All PRV-infected TG neurons were in a stably suppressed quiescent state of infection after type I IFN pretreatment. More specifically, it was demonstrated that type I IFN decreases PRV IE180 protein expression level in sensory neuronal cells, allowing for the establishment of a quiescent state [135]. Pretreatment of axons with type I IFN significantly reduced the number of PRV particles moving in axons towards the cell bodies of rat PNS neurons [136]. In addition, Lamote and colleagues demonstrated that PRV-Becker inhibits the IFN response in swine dendritic cells while PRV-Bartha induces a strong type I IFN response in these cells. This difference was attributed to the absence of the immunomodulatory glycoprotein gE/gI gene complex, in the genome of Bartha [137]. So far, the level of type I IFN has not been quantified in the swine URT and compared between PRV-Becker and PRV-Bartha infections. Therefore, it is not known whether the PRV gE/gI complex similarly inhibits the type I IFN response in the swine respiratory epithelium. If so, additional antiviral factors, other than the induction of a strong type I IFN response, may exist further restricting primary PRV infection in pigs. For instance, a group of antiviral restriction factors, the IFN-inducible transmembrane proteins (IFITMs) have been shown to inhibit PRV replication in porcine kidney epithelial (PK-15) cells and porcine alveolar macrophages. Porcine IFTM1 specifically inhibited PRV entry in these cells [138]. Furthermore, a porcine IFN-stimulated ubiquitin-like protein (PISG15) efficiently inhibited PRV infection by reducing viral titers and increasing type I IFN expression in vitro [139].

In addition to its role in reducing viral replication, type I IFN plays a crucial role in regulating the early neuroinflammatory response and clinical outcome of PRV infection in mice [60]. In the footpad inoculation model, PRV-Bartha infection, but not PRV-Becker, induces a strong type IIFN response in the footpad and DRG neurons of inoculated mice, which in turn fails to trigger an inflammatory response in those tissues. Surprisingly, PRV-Bartha infection of type I IFN KO mice induces the production of pro-inflammatory cytokines, such as G-CSF in DRG neurons. Therefore, PRV-Becker infection may trigger a massive inflammatory response in mice because this virulent strain can suppress the IFN response. The imbalance of pro-inflammatory and antiviral immune responses might contribute to the distinct clinical outcomes of PRV-Becker and Bartha infections in mice. In addition, during PRV-Becker infection, the rapid priming of DRG neurons to an inflammatory state may initiate the neuropathic itch in mice as the infection of the PNS proceeds.

Taken together, these studies emphasize the essential role of the type I IFN response in controlling PRV replication in the swine respiratory epithelium. This control may prevent the productive PNS infection and the induction of a powerful inflammatory response, which may be the reason why infected pigs do not show itch symptoms. 


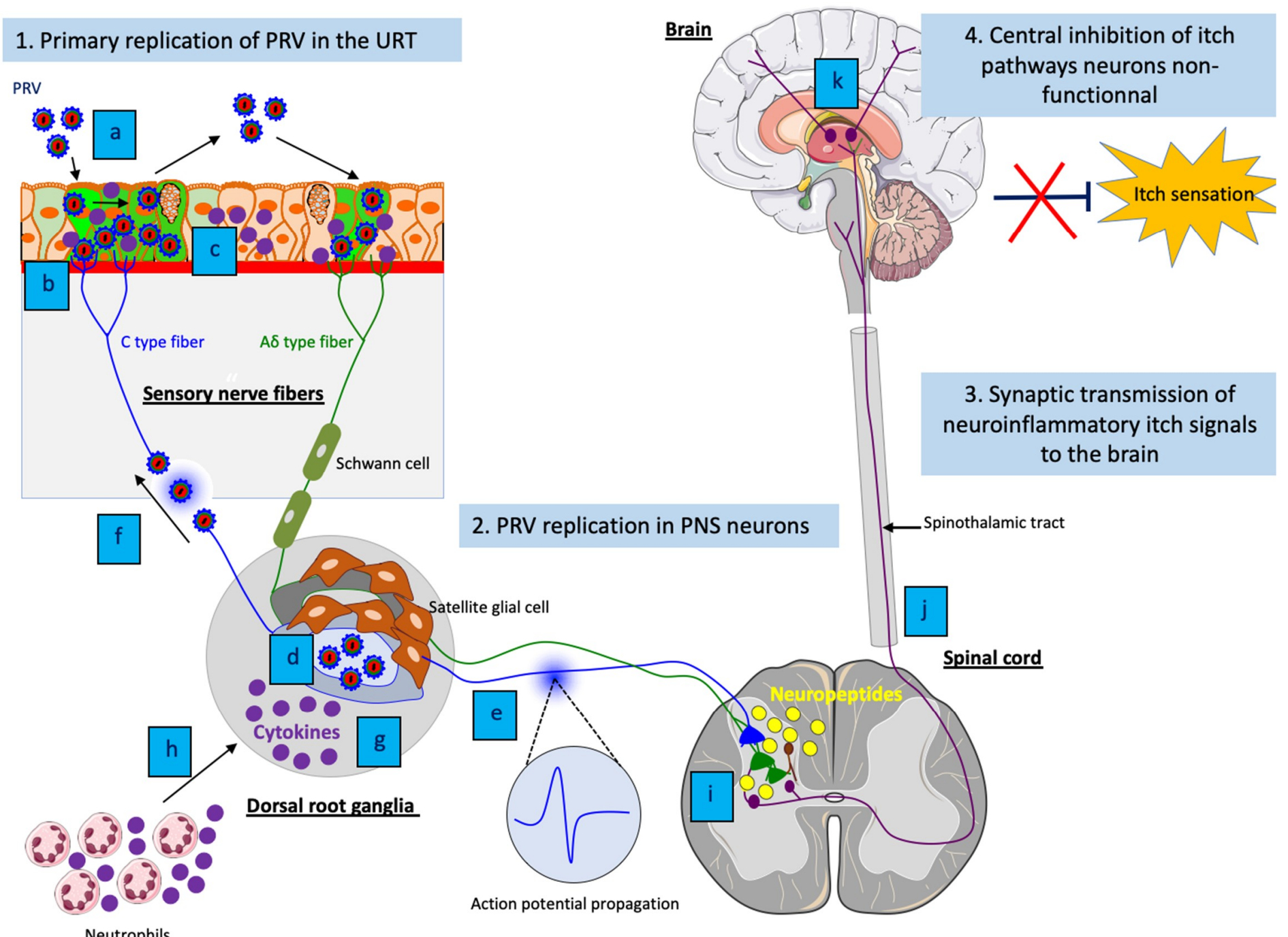

Figure 3. Model of PRV-induced neuropathic itch in non-natural hosts. (1) (a) Efficient viral replication and spread of PRV in the respiratory epithelium; (b) PRV particles activate axons terminals of sensory PNS neurons; (c) Activated sensory PNS neurons trigger inflammatory signaling pathways and produce pro-inflammatory 
cytokines that are released in PNS neurons and locally at axon terminals. (2) (d) Efficient PRV replication in cell bodies of PNS neurons and release of new progeny virions; (e) Spontaneous hyperexcitability of neurons and increase of action potential firing as well as (f) reseeding of new progeny virions back to the epithelium increases electrical coupling of axons and contributes to the pruritus; (b) Amplification of the inflammatory response in PNS neurons; (h) The production of pro-inflammatory cytokines in PNS neurons attract neutrophils and other immune cells to the site of infection and propagate the neuroinflammation. (3) (i) Release of neuropeptides from activated PNS neurons stimulate excitative interneurons in the dorsal horn of the spinal cord; (j) The excitation spreads to spinothalamic tract neurons, which in turn send neuroinflammatory itch signals to the brain; (k) These signals are relayed and processed in the somatosensory cortex. (4) The central itch inhibition pathways are likely dampened or disabled, resulting in an unstoppable pruritus. 


\section{PRV Infection in Mice: A New Animal Model for VZV-Induced Peripheral Neuropathies}

A better understanding of PRV-induced neuroinflammatory responses in mice may provide new insights in the initiation and development of virus-induced neuroinflammation during other herpesvirus infections. For instance, this animal model could be useful to dissect the mechanisms of neuropathic itch in patients with post-herpetic lesions (e.g., herpes zoster (HZ); shingles). Indeed, the neuropathogenesis and immunopathogenesis of VZV and PRV infections are remarkably similar. Reactivation of VZV causes a self-limited dermatomal rash with pain and itching, which is accompanied by inflammation of the skin [124]. The HZ lesions can be reduced by treatment with antivirals [140]. However, postherpetic neuralgia (PHN) and postherpetic itch (PHI) are two common complications of HZ that can occur in some cases in up to $50 \%$ of patients with shingles [101,141].

PHN consists of a burning and stabbing pain while PHI is characterized by a relentless itch in the same area of the HZ rash, resulting in serious injuries due to scratching. Both PHN and PHI can last for months or years after resolution of the $\mathrm{HZ}$ rash, thus severely impacting the life quality of infected people. Antiviral therapy for acute $\mathrm{HZ}$ does not eliminate the risk of PHN, and no beneficial effect of any antiviral drug on established PHN has been shown [142]. It was suggested that PHN is caused by VZV-induced inflammation and axonal damage, which gives rise to hyperexcitability, marked by spontaneous firing of PNS neurons. These neurons may have a lower excitation threshold to pain, thus causing neuropathic pain $[143,144]$. In contrast, the underlying mechanism(s) of PHI is largely unknown. Despite some similarities between itch and pain pathways, treatments against pain are not efficient in relieving itch. Current treatments against neuropathic itch are very limited and lack specificity, and for many patients with PHI no alleviation can be provided [145].

The narrow host range and lack of clinical disease have limited the use of animal models to investigate the pathogenesis of VZV infection [146]. So far, investigation of PHI has been limited by the lack of a relevant in vivo neuropathic itch animal model. Interestingly, VZV and PRV infections present multiple similarities in genome sequence, clinical signs, pathogenesis and immunity. At the level of innate immunity, the exact same concentration of IL-6 $(\sim 30,000 \mathrm{pg} / \mathrm{mL})$ has been demonstrated in both VZV-infected human explants and PRV-infected mouse footpad by ELISA [81,147]. Since VZV does not productively replicate in rodents, PRV-induced neuropathic itch in mice may represent a promising model to further understand the pathogenesis of PHI caused by VZV infection.

\section{Conclusions}

Since the first case of mad itch was described 207 years ago, the characteristic pruritus caused by PRV infection in non-natural hosts has been frequently reported throughout the years. Currently, relatively few studies have focused on this particular aspect of PRV pathogenesis. This paucity of information is mainly because PRV remained a major viral disease in swine, causing substantial economic losses to pig producers. Therefore, the efforts of the research community were primarily focused on developing effective vaccines aimed at eradication of the virus. In this review, we highlight the more fundamental studies that focus on differences in the pathogenesis of PRV between pigs and non-natural hosts. These studies may explain the distinct clinical outcomes. Recently, researchers dissected the molecular and cellular mechanisms of PRV-induced neuropathic itch using several mouse models and emphasized the innate immune response as a central player. Good control of the inflammatory response during PRV infection of swine likely prevents the neuropathic pruritus experienced by infected non-natural hosts. Most importantly, PRV infection of mice has proven to be a suitable animal model to study PRV-induced neuropathic itch. This animal model may also provide useful insights into the pathogenesis of other herpesvirus infections, such as those following VZV infection. The model may lead to the development of innovative therapeutic strategies. Finally, this model may guide research on peripheral neuropathies such as multiple sclerosis and associated viral-induced damage to the PNS as well as other neurodegenerative processes. 
Author Contributions: K.L. suggested the idea and wrote the review. L.W.E. critically reviewed, corrected and guided the completion of the review. All authors read and approved the final manuscript.

Funding: This research was funded by National Institute of Neurological Disorders and Stroke (NINDS) grants RO1 NS33506 and NS060699.

Acknowledgments: K.L and L.W.E. are thankful to the National Institute of Neurological Disorders and Stroke (NINDS) grants RO1 NS33506 and NS060699 that funded this research.

Conflicts of Interest: The authors declare that they have no competing interests.

\section{References}

1. Aujeszky, A. Uber eine neue Infektion krankheit bei Haustieren. Zbl Bakt Abt Orig 1902, 32, 353-357.

2. Schmiedhoffer, J. Beiträge zur Pathologieder infektiösen Bulbär paralyse (Aujeszky-schen Krankheit). Z. Infekt. Krankh. Parasit. Hyg. Haustier 1910, 8, 383-405.

3. Shope, R.E. An experimental study of 'mad itch' with especial reference to its relationship to pseudorabies. J. Exp. Med. 1931, 54, 233-248. [CrossRef] [PubMed]

4. Shope, R.E. Pseudorabies is a contagious disease in swine. Science 1934, 80, 102-103. [CrossRef] [PubMed]

5. Sabin, A.B. Studies on the B virus. The immunological identity of a virus isolated from a human case of ascending myelitis associated with visceral necrosis. I. Br. J. Exp. Pathol. 1934, 15, 248-268.

6. Sabin, A.B.A.W.; Wright, A.M. Acute ascending myelitis following monkey bite with isolation of a virus capable of reproducing disease. J. Exp. Med. 1934, 59, 115. [CrossRef]

7. Sabin, A.B. Progression of different nasally installed viruses along different nervous pathways in the same host. Proc. Soc. Exp. Biol. Med. 1938, 38, 270-275. [CrossRef]

8. Freuling, C.M.; Müller, T.F.; Mettenleiter, T.C. Vaccines against pseudorabies virus (PrV). Vet. Microbiol. 2017, 206, 3-9. [CrossRef]

9. Zhao, W.L.; Wu, Y.H.; Li, H.F.; Li, S.Y.; Fan, S.Y.; Wu, H.L.; Li, Y.J.; Lu, Y.L.; Han, J. Clinical experience and next-generation sequencing analysis of encephalitis caused by pseudorabies virus. Zhonghua Yi Xue Za Zhi 2018, 98, 1152-1157.

10. Ai, J.W.; Weng, S.S.; Cheng, Q.; Cui, P.; Li, Y.J.; Wu, H.L.; Zhu, Y.M.; Xu, B.; Zhang, W.H. Human Endophthalmitis Caused By Pseudorabies Virus Infection, China, 2017. Emerg. Infect. Dis. 2018, 24, 1087-1090. [CrossRef]

11. Gu, J.; Hu, D.; Peng, T.; Wang, Y.; Ma, Z.; Liu, Z.; Meng, F.; Shang, Y.; Liu, S.; Xiao, Y. Epidemiological investigation of pseudorabies in Shandong Province from 2013 to 2016. Transbound Emerg Dis. 2018, 65, 890-898. [CrossRef]

12. Liu, Y.; Zhang, S.; Xu, Q.; Wu, J.; Zhai, X.; Li, S.; Wang, J.; Ni, J.; Yuan, L.; Song, X.; et al. Investigation on pseudorabies prevalence in Chinese swine breeding farms in 2013-2016. Trop Anim. Health Prod. 2018, 50, 1279-1285. [CrossRef]

13. Skinner, G.R.B.; Ahmad, A.; Davies, J.A. The infrequency of transmission of herpesviruses between humans and animals; postulation of an unrecognized protective host mechanism. Comp. Immunol. Microbiol. Infect. Dis. 2001, 24, 255-269. [CrossRef]

14. Nauwynck, H.; Glorieux, S.; Favoreel, H.; Pensaert, M. Cell biological and molecular characteristics of pseudorabies virus infections in cell cultures and in pigs with emphasis on the respiratory tract. Vet. Res. 2007, 38, 229-241. [CrossRef] [PubMed]

15. Mettenleiter, T.C. Aujeszky's disease (pseudorabies) virus: The virus and molecular pathogenesis-State of the art, June 1999. Vet. Res. 2000, 31, 99-115. [CrossRef] [PubMed]

16. Pomeranz, L.E.; Reynolds, A.E.; Hengartner, C.J. Molecular biology of pseudorabies virus: Impact on neurovirology and veterinary medicine. Microbiol. Mol. Biol. Rev. 2005, 69, 462-500. [CrossRef]

17. Steiner, I.; Kennedy, P.G.E.; Pachner, A.R. The neurotropic herpes viruses: Herpes simplex and varicella-zoster. Lancet Neurol. 2007, 6, 1015-1028. [CrossRef]

18. Roizmann, B.; Desrosiers, R.C.; Fleckenstein, B.; Lopez, C.; Minson, A.C.; Studdert, M.J. The family Herpesviridae: An update. The Herpesvirus Study Group of the International Committee on Taxonomy of Viruses. Arch. Virol. 1992, 123, 425-449. [CrossRef]

19. Ben-Porat, T.; Kaplan, A.S. Molecular Biology of Pseudorabies Virus. In The herpesviruses; Roizman, B., Ed.; Plenum Press: New York, NY, USA, 1985; Volume 3, pp. 105-173. 
20. Klupp, B.G.; Hengartner, C.J.; Mettenleiter, T.C.; Enquist, L.W. Complete, annotated sequence of the pseudorabies virus genome. J. Virol. 2004, 78, 424-440. [CrossRef]

21. Mettenleiter, T.C. Herpesvirus assembly and egress. J. Virol. 2002, 76, 1537-1547. [CrossRef]

22. Roizmann, B.F.D. The Replication of Herpesviruses. In Comprehensive Virology; Fraenkel-Conrat, H., RWagner, R., Eds.; Plenum Press: New York, NY, USA, 1974; pp. 229-403.

23. Crabb, B.S.; Nagesha, H.S.; Studdert, M. Identification of equine herpesvirus 4 glycoprotein G: A type-specific, secreted glycoprotein. Virology 1992, 190, 143-154. [CrossRef]

24. Salwa, A. A natural outbreak of Aujeszky's disease in farm animals. Pol. J. Vet. Sci. 2004, 7, $261-266$. [PubMed]

25. Steinrigl, A.; Revilla-Fernandez, S.; Kolodziejek, J.; Wodak, E.; Bago, Z.; Nowotny, N.; Schmoll, F.; Kofer, J. Detection and molecular characterization of Suid herpesvirus type 1 in Austrian wild boar and hunting dogs. Vet. Microbiol. 2012, 157, 276-284. [CrossRef] [PubMed]

26. Thaller, D.; Bilek, A.; Revilla-Fernandez, S.; Bago, Z.; Schildorfer, H.; URL, A.; Weikel, J.; Weissenbock, H. Nachweis von Aujeszkyscher krankheit bei einem hund in Osterreich. Vet. Med. Austria. 2006, 93, 62-67.

27. Cay, A.L.C. Isolation of anjeszky's disease virus from two hunting dogs in Belgium after hunting wild boars. Vlaams Diergeneeskd. Tijdschr. 2009, 78, 194-195.

28. Marcaccini, A.; Lopez Pena, M.; Quiroga, M.I.; Bermudez, R.; Nieto, J.M.; Aleman, N. Pseudorabies virus infection in mink: A host-specific pathogenesis. Vet. Immunol. Immunopathol. 2008, 124, 264-273. [CrossRef]

29. Leschnik, M.; Gruber, A.; Kubber-Heiss, A.; Bago, Z.; Revilla-Fernandez, S.; Wodak, E.; Muller, E. Epidemiologische aspekte der Aujeskyschen krankheit in Osterrreich anhand von sechs aktuellen fallen beim hund. Wiener Tierarztliche Monatsschrift 2012, 99, 82-90.

30. Cramer, S.D.; Campbell, G.A.; Njaa, B.L.; Morgan, S.E.; Smith, S.K., 2nd; McLin, W.R.t.; Brodersen, B.W.; Wise, A.G.; Scherba, G.; Langohr, I.M.; et al. Pseudorabies virus infection in Oklahoma hunting dogs. J. Vet. Diagn. Investig. 2011, 23, 915-923. [CrossRef]

31. Zhang, L.; Zhong, C.; Wang, J.; Lu, Z.; Liu, L.; Yang, W.; Lyu, Y. Pathogenesis of natural and experimental Pseudorabies virus infections in dogs. J. Virol. 2015, 12, 44. [CrossRef]

32. Schoniger, S.; Klose, K.; Werner, H.; Schwarz, B.A.; Muller, T.; Schoon, H.A. Nonsuppurative encephalitis in a dog. Vet. Pathol. 2012, 49, 731-734. [CrossRef]

33. Kong, H.; Zhang, K.; Liu, Y.; Shang, Y.; Wu, B.; Liu, X. Attenuated live vaccine (Bartha-K16) caused pseudorabies (Aujeszky's disease) in sheep. Vet. Res. Commun. 2013, 37, 329-332. [CrossRef] [PubMed]

34. Moreno, A.; Sozzi, E.; Grilli, G.; Gibelli, L.R.; Gelmetti, D.; Lelli, D.; Chiari, M.; Prati, P.; Alborali, G.L.; Boniotti, M.B.; et al. Detection and molecular analysis of Pseudorabies virus strains isolated from dogs and a wild boar in Italy. Vet. Microbiol. 2015, 177, 359-365. [CrossRef] [PubMed]

35. Caruso, C.; Dondo, A.; Cerutti, F.; Masoero, L.; Rosamilia, A.; Zoppi, S.; D’Errico, V.; Grattarola, C.; Acutis, P.L.; Peletto, S. Aujeszky's Disease in Red Fox (Vulpes vulpes): Phylogenetic Analysis Unravels an Unexpected Epidemiologic Link. J. Wildl. Dis. 2014, 50, 707-710. [CrossRef] [PubMed]

36. Liu, H.; Li, X.T.; Hu, B.; Deng, X.Y.; Zhang, L.; Lian, S.Z.; Zhang, H.L.; Lv, S.; Xue, X.H.; Lu, R.G.; et al. Outbreak of severe pseudorabies virus infection in pig-offal-fed farmed mink in Liaoning Province, China. Arch Virol. 2017, 162, 863-866. [CrossRef] [PubMed]

37. Wang, G.S.; Du, Y.; Wu, J.Q.; Tian, F.L.; Yu, X.J.; Wang, J.B. Vaccine resistant pseudorabies virus causes mink infection in China. BMC Vet. Res. 2018, 14, 20. [CrossRef] [PubMed]

38. Jin, H.L.; Gao, S.M.; Liu, Y.; Zhang, S.F.; Hu, R.L. Pseudorabies in farmed foxes fed pig offal in Shandong province, China. Arch. Virol. 2016, 161, 445-448. [CrossRef]

39. Pedersen, K.; Turnage, C.T.; Gaston, W.D.; Arruda, P.; Alls, S.A.; Gidlewski, T. Pseudorabies detected in hunting dogs in Alabama and Arkansas after close contact with feral swine (Sus scrofa). BMC Vet. Res. 2018, 14, 388. [CrossRef]

40. Masot, A.J.; Gil, M.; Risco, D.; Jimenez, O.M.; Nunez, J.I.; Redondo, E. Pseudorabies virus infection (Aujeszky's disease) in an Iberian lynx (Lynx pardinus) in Spain: A case report. BMC Vet. Res. 2017, 13, 6. [CrossRef]

41. Lian, K.; Zhang, M.; Zhou, L.; Song, Y.; Wang, G.; Wang, S. First report of a pseudorabies-virus-infected wolf (Canis lupus) in China. Arch. Virol. 2019. [CrossRef]

42. Lazic, G.; Lupulovic, D.; Topalski, B.; Bozić, B.; Lazic, S. Aujeszky's disease in a dog-Case report. Arh. Vet. Med. 2017, 10, 61-69. 
43. Serena, M.S.; Metz, G.E.; Lozada, M.I.; Aspitia, C.G.; Nicolino, E.H.; Pidone, C.L.; Fossaroli, M.; Balsalobre, A.; Quiroga, M.A.; Echeverria, M.G. First isolation and molecular characterization of Suid herpesvirus type 1 from a domestic dog in Argentina. Open Vet. J. 2018, 8, 131-139. [CrossRef] [PubMed]

44. Cheng, Z.; Kong, Z.; Liu, P.; Fu, Z.; Zhang, J.; Liu, M.; Shang, Y. Natural infection of a variant pseudorabies virus leads to bovine death in China. Transbound Emerg Dis. 2019. [CrossRef] [PubMed]

45. Yang, H.; Han, H.; Wang, H.; Cui, Y.; Liu, H.; Ding, S.A. Case of Human Viral Encephalitis Caused by Pseudorabies Virus Infection in China. Front. Neurol. 2019, 10, 534. [CrossRef] [PubMed]

46. Yang, X.; Guan, H.; Li, C.; Li, Y.; Wang, S.; Zhao, X.; Zhao, Y.; Liu, Y. Characteristics of human encephalitis caused by pseudorabies virus: A case series study. Int. J. Infect. Dis. 2019, 87, 92-99. [CrossRef]

47. Wang, Y.; Nian, H.; Li, Z.; Wang, W.; Wang, X.; Cui, Y. Human encephalitis complicated with bilateral acute retinal necrosis associated with pseudorabies virus infection: A case report. Int. J. Infect. Dis. 2019, 89, 51-54. [CrossRef]

48. Wang, D.; Tao, X.; Fei, M.; Chen, J.; Guo, W.; Li, P.; Wang, J. Human encephalitis caused by pseudorabies virus infection: A case report. J. Neurovirol. 2020. [CrossRef]

49. Hahn, E.C.; Page, G.R.; Hahn, P.S.; Gillis, K.D.; Romero, C.; Annelli, J.A.; Gibbs, E.P. Mechanisms of transmission of Aujeszky's disease virus originating from feral swine in the USA. Vet. Microbiol. 1997, 55, 123-130. [CrossRef]

50. Romero, C.H.; Meade, P.N.; Shultz, J.E.; Chung, H.Y.; Gibbs, E.P.; Hahn, E.C.; Lollis, G. Venereal transmission of pseudorabies viruses indigenous to feral swine. J. Wildl. Dis. 2001, 37, 289-296. [CrossRef]

51. Kluge, J.P.; Beran, G.W.; Hill, H.T.; Platt, K.B. Pseudorabies (Aujeszky's Disease). In Diseases of swine, 8th ed.; Straw, B.E., D’Allaire, S., Mengeling, W.L., Taylor, D.J., Eds.; Iowa State University Press: Ames, IA, USA, 1999; pp. 233-246.

52. Miry, C.P. Aujeszky's Disease Virus Replication in Tonsils and Respiratory Tract of non-Immune and Immune Pigs. In Vaccination and Control of Aujeszky's disease; van Oirschot, J.T., Ed.; Kluwer Academic Publishers: Dordrecht, The Netherlands, 1989; pp. 163-173.

53. Wittmann, G. Aujeszky's Disease (Pseudorabies) in Pigs. In Herpesvirus Diseases of Cattle, Horses and Pigs; Knipe, D.M., Howley, P.M., Eds.; Kluwer Academic Publishers: Boston, MA, USA, 1989; pp. 230-325.

54. Masic, M.; Ercegan, M.; Petrovic, M. The significance of the tonsils in the pathogenesis and diagnosis of Aujeszyk's disease in pigs. Zent. Vet. B 1965, 12, 398-405.

55. Glorieux, S.; Van den Broeck, W.; van der Meulen, K.M.; Van Reeth, K.; Favoreel, H.W.; Nauwynck, H.J. In vitro culture of porcine respiratory nasal mucosa explants for studying the interaction of porcine viruses with the respiratory tract. J. Virol. Methods 2007, 142, 105-112. [CrossRef]

56. Glorieux, S.; Favoreel, H.W.; Meesen, G.; de Vos, W.; Van den Broeck, W.; Nauwynck, H.J. Different replication characteristics of historical pseudorabies virus strains in porcine respiratory nasal mucosa explants. Vet. Microbiol. 2009, 136, 341-346. [CrossRef] [PubMed]

57. Narita, M.; Kawashima, K.; Matsuura, S.; Uchimura, A.; Miura, Y. Pneumonia in pigs infected with pseudorabies virus and Haemophilus parasuis serovar 4. J. Comp. Pathol. 1994, 110, 329-339. [CrossRef]

58. Maes, R.K.; Kanitz, C.L.; Gustafson, D.P. Shedding patterns in swine of virulent and attenuated pseudorabies virus. Am. J. Vet. Res. 1983, 44, 2083-2086. [PubMed]

59. Babic, N.; Mettenleiter, T.C.; Ugolini, G.; Flamand, A.; Coulon, P. Propagation of pseudorabies virus in the nervous system of the mouse after intranasal inoculation. Virology 1994, 204, 616-625. [CrossRef] [PubMed]

60. Laval, K.; Van Cleemput, J.; Vernejoul, J.B.; Enquist, L.W. Alphaherpesvirus infection of mice primes PNS neurons to an inflammatory state regulated by TLR2 and type I IFN signaling. PLoS Pathog. 2019, 15, e1008087. [CrossRef]

61. Brittle, E.E.; Reynolds, A.E.; Enquist, L.W. Two modes of pseudorabies virus neuroinvasion and lethality in mice. J. Virol. 2004, 78, 12951-12963. [CrossRef]

62. Field, H.J.; Hill, T.J. The pathogenesis of pseudorabies in mice following peripheral inoculation. J. Gen. Virol. 1974, 23, 145-157. [CrossRef]

63. Grinde, B. Herpesviruses: Latency and reactivation-Viral strategies and host response. J. Oral Microbiol. 2013, 5. [CrossRef]

64. Tirabassi, R.S.; Townley, R.A.; Eldridge, M.G.; Enquist, L.W. Molecular mechanisms of neurotropic herpesvirus invasion and spread in the CNS. Neurosci. Biobehav. Rev. 1998, 22, 709-720. [CrossRef] 
65. Gutekunst, D.E.; Pirtle, E.C.; Miller, L.D.; Stewart, W.C. Isolation of pseudorabies virus from trigeminal ganglia of a latently infected sow. Am. J. Vet. Res. 1980, 41, 1315-1316.

66. Wheeler, J.G.; Osorio, F.A. Investigation of sites of pseudorabies virus latency, using polymerase chain reaction. Am. J. Vet. Res. 1991, 52, 1799-1803. [PubMed]

67. Van Oirschot, J.T.; Gielkens, A.L. In vivo and in vitro reactivation of latent pseudorabies virus in pigs born to vaccinated sows. Am. J. Vet. Res. 1984, 45, 567-571. [PubMed]

68. Wigdahl, B.; Rong, B.L.; Kinney-Thomas, E. Varicella-zoster virus infection of human sensory neurons. Virology 1986, 152, 384-399. [CrossRef]

69. Jones, C. Bovine Herpes Virus 1 (BHV-1) and Herpes Simplex Virus Type 1 (HSV-1) Promote Survival of Latently Infected Sensory Neurons, in Part by Inhibiting Apoptosis. J. Cell Death 2013, 6, 1-16. [CrossRef]

70. Olson, G.R.; Miller, L.D. Studies on the pathogenesis of heart lesions in dogs infected with pseudorabies virus. Can. J. Vet. Res. 1986, 50, 245-250.

71. Damann, N.; Klopfleisch, R.; Rothermel, M.; Doerner, J.F.; Mettenleiter, T.C.; Hatt, H.; Wetzel, C.H. Neuronal pathways of viral invasion in mice after intranasal inoculation of pseudorabies virus PrV-9112C2 expressing bovine herpesvirus 1 glycoprotein B. J. Neurovirol. 2006, 12, 60-64. [CrossRef]

72. Lamote, J.A.S.; Glorieux, S.; Nauwynck, H.J.; Favoreel, H.W. The US3 Protein of Pseudorabies Virus Drives Viral Passage across the Basement Membrane in Porcine Respiratory Mucosa Explants. J. Virol. 2016, 90, 10945-10950. [CrossRef]

73. Glorieux, S.; Favoreel, H.W.; Steukers, L.; Vandekerckhove, A.P.; Nauwynck, H.J. A trypsin-like serine protease is involved in pseudorabies virus invasion through the basement membrane barrier of porcine nasal respiratory mucosa. Vet. Res. 2011, 42, 58. [CrossRef]

74. Jamrichova, O.; Skoda, R. Multiplication of pseudorabies virus in the inguinal lymph nodes of pigs. Acta Virol. 1968, 12, 555.

75. Wittmann, G.; Ohlinger, V.; Rziha, H.J. Occurrence and reactivation of latent Aujeszky's disease virus following challenge in previously vaccinated pigs. Arch. Virol. 1983, 75, 29-41. [CrossRef]

76. Mulder, W.A.; Jacobs, L.; Priem, J.; Kok, G.L.; Wagenaar, F.; Kimman, T.G.; Pol, J.M. Glycoprotein gE-negative pseudorabies virus has a reduced capability to infect second- and third-order neurons of the olfactory and trigeminal routes in the porcine central nervous system. J. Gen. Virol. 1994, 75, 3095-3106. [CrossRef] [PubMed]

77. Sabo, A.; Rajcani, J.; Blaskovic, D. Studies on the pathogenesis of Aujeszky's disease virus. III. The distribution of virulent virus in piglets after intranasal infection. Acta Virol. 1969, 13, 407-714. [PubMed]

78. Nauwynck, H.J.; Pensaert, M.B. Interactions of Aujeszky's disease virus and porcine blood mononuclear cells in vivo and in vitro. Acta Vet. Hung. 1994, 42, 301-308. [PubMed]

79. Nawynck, H.J.; Pensaert, M.B. Cell-free and cell-associated viremia in pigs after oronasal infection with Aujeszky's disease virus. Vet. Microbiol. 1995, 43, 307-314. [CrossRef]

80. Mc Ferran, I.B.; Dow, C. Virus studies on experimental Aujeszky's disease in calves. J. Comp. Pathol. 1964, 74, 173-179. [CrossRef]

81. Laval, K.; Vernejoul, J.B.; Van Cleemput, J.; Koyuncu, O.O.; Enquist, L.W. Virulent Pseudorabies Virus Infection Induces a Specific and Lethal Systemic Inflammatory Response in Mice. J. Virol. 2018, 92, e01614-18. [CrossRef]

82. Nauwynck, H.J.; Pensaert, M.B. Abortion induced by cell-associated pseudorabies virus in vaccinated sows. Am. J. Vet. Res. 1992, 53, 489-493.

83. Kluge, J.P.; Mare, C.J. Swine pseudorabies: Abortion, clinical disease, and lesions in pregnant gilts infected with pseudorabies virus (Aujeszky's disease). Am. J. Vet. Res. 1974, 35, 991-995.

84. Hsu, F.S.; Chu, R.M.; Lee, R.C.; Chu, S.H. Placental lesions caused by pseudorabies virus in pregnant sows. J. Am. Vet. Med. Assoc. 1980, 177, 636-641.

85. Van de Walle, G.R.; Favoreel, H.W.; Nauwynck, H.J.; Mettenleiter, T.C.; Pensaert, M.B. Transmission of pseudorabies virus from immune-masked blood monocytes to endothelial cells. J. Gen. Virol. 2003, 84, 629-637. [CrossRef]

86. Ka,H.; Seo, H.; Choi, Y.; Yoo, I.; Han, J. Endometrial response to conceptus-derived estrogen and interleukin-1 $\beta$ at the time of implantation in pigs. J. Anim. Sci. Biotechnol. 2018, 9, 44. [CrossRef] [PubMed]

87. Velez, C.; Barbeito, C.; Koncurat, M. alphavbeta3 Integrin and fibronectin expressions and their relation to estrogen and progesterone during placentation in swine. Biotech. Histochem. 2018, 93, 15-24. [PubMed] 
88. Bidarimath, M.; Tayade, C. Pregnancy and spontaneous fetal loss: A pig perspective. Mol. Reprod. Dev. 2017, 84, 856-869. [CrossRef] [PubMed]

89. Dieuzy, I.; Vannier, P.; Jestin, A. Effects of experimental pseudorabies virus infection on vaccinated pregnant sows. Ann. Rech. Vet. 1987, 18, 233-240.

90. Iglesias, J.G.; Harkness, J.W. Studies of transplacental and perinatal infection with two clones of a single Aujeszky's disease (pseudorabies) virus isolate. Vet. Microbiol. 1988, 16, 243-254. [CrossRef]

91. Ceriatti, F.S.; Sabini, L.I.; Bettera, S.G.; Zanon, S.M.; Ramos, B.A. Experimental infection of pregnant gilts with Aujeszky's disease virus strain RC/79. Rev. Argent Microbiol. 1992, 24, 102-112.

92. Ezura, K.; Usami, Y.; Tajima, K.; Komaniwa, H.; Nagai, S.; Narita, M.; Kawashima, K. Gastrointestinal and skin lesions in piglets naturally infected with pseudorabies virus. J. Vet. Diagn. Investig. 1995, 7, 451-455. [CrossRef]

93. Ständer, S.; Weisshaar, E.; Mettang, T.; Szepietowski, J.C.; Carstens, E.; Ikoma, A.; Bergasa, N.V.; Gieler, U.; Misery, L.; Wallengren, J.; et al. Clinical classification of itch: A position paper of the International Forum for the Study of Itch. Acta Derm. Venereol. 2007, 87, 291-294. [CrossRef]

94. Ikoma, A.; Steinhoff, M.; Ständer, S.; Yosipovitch, G.; Schmelz, M. The neurobiology of itch. Nat. Rev. Neurosci. 2006, 7, 535-547. [CrossRef]

95. Grundmann, S.; Stander, S. Chronic pruritus: Clinics and treatment. Ann. Dermatol. 2011, 23, 1-11. [CrossRef]

96. Green, D.; Dong, X. The cell biology of acute itch. J. Cell. Biol. 2016, 213, 155-161. [CrossRef] [PubMed]

97. Yosipovitch, G.; Fleischer, A. Itch associated with skin disease: Advances in pathophysiology and emerging therapies. Am. J. Clin. Dermatol. 2003, 4, 617-622. [CrossRef] [PubMed]

98. Galatian, A.; Stearns, G.; Grau, R. Pruritus in connective tissue and other common systemic disease states. Cutis 2009, 84, 207-214. [PubMed]

99. Binder, A.; Koroschetz, J.; Baron, R. Disease mechanisms in neuropathic itch. Nat. Clin. Pract. Neurol. 2008, 4, 329-337. [CrossRef]

100. Yosipovitch, G.; Samuel, L.S. Neuropathic and psychogenic itch. Dermatol. Ther. 2008, 21, 32-41. [CrossRef]

101. Oaklander, A.L. Neuropathic itch. Semin. Cutan. Med. Surg. 2011, 30, 87-92. [CrossRef]

102. Ringkamp, M.; Meyer, R. Itch: Mechanisms and treatment; Carstens, E., Akiyama, T., Eds.; Frontiers in Neuroscience Pruriceptors; CRC Press/Taylor \& Francis(c), LLC: Boca Raton, FL, USA, 2014.

103. Robbins, B.A.; Schmieder, G.J. Brachioradial Pruritus. In StatPearls; StatPearls Publishing StatPearls Publishing LLC.: Treasure Island, FL, USA, 2020.

104. Mittal, A.; Srivastava, A.; Balai, M.; Khare, A.K. A study of postherpetic pruritus. Indian Dermatol. Online J. 2016, 7, 343-344. [CrossRef]

105. Yamamoto, M.; Yabuki, S.; Hayabara, T.; Otsuki, S. Paroxysmal itching in multiple sclerosis: A report of three cases. J. Neurol. Neurosurg. Psychiatry 1981, 44, 19-22. [CrossRef]

106. Koeppel, M.C.; Bramont, C.; Ceccaldi, M.; Habib, M.; Sayag, J. Paroxysmal pruritus and multiple sclerosis. Br. J. Dermatol. 1993, 129, 597-598. [CrossRef]

107. King, C.A.; Huff, F.J.; Jorizzo, J.L. Unilateral neurogenic pruritus: Paroxysmal itching associated with central nervous system lesions. Ann. Intern. Med. 1982, 97, 222-223. [CrossRef]

108. Steinhoff, M.; Schmelz, M.; Szabó, I.L.; Oaklander, A.L. Clinical presentation, management, and pathophysiology of neuropathic itch. Lancet Neurol. 2018, 17, 709-720. [CrossRef]

109. Davidson, S.; Zhang, X.; Khasabov, S.G.; Simone, D.A.; Giesler, G.J., Jr. Relief of itch by scratching: State-dependent inhibition of primate spinothalamic tract neurons. Nat. Neurosci. 2009, 12, 544-546. [CrossRef] [PubMed]

110. Yosipovitch, G.; Ishiuji, Y.; Patel, T.S.; Hicks, M.I.; Oshiro, Y.; Kraft, R.A.; Winnicki, E.; Coghill, R.C. The Brain Processing of Scratching. J. Investig. Dermatol. 2019, 128, 1806-1811. [CrossRef] [PubMed]

111. Dempsher, J.; Larrabee, M.G.; Bang, F.B.; Bodian, D. Physiological changes in sympathetic ganglia infected with pseudorabies virus. Am. J. Physiol. 1955, 182, 203-216. [CrossRef]

112. Tokumaru, T. Pseudorabies virus-Induced neural hyperreactivity following occular and skin infections in the rat. Res. Commun. Chem. Pathol. Pharmacol. 1975, 10, 533-542.

113. Dolivo, M.; Beretta, E.; Bonifas, V.; Foroglou, C. Ultrastructure and function in sympathetic ganglia isolated from rats infected with pseudorabies virus. Brain Res. 1978, 140, 111-123. [CrossRef]

114. Liao, G.S.; Maillard, M.; Kiraly, M. Ion channels involved in the presynaptic hyperexcitability induced by herpes virus suid in rat superior cervical ganglion. Neuroscience 1991, 41, 797-807. [CrossRef] 
115. McCarthy, K.M.; Tank, D.W.; Enquist, L.W. Pseudorabies virus infection alters neuronal activity and connectivity in vitro. PLoS Pathog. 2009, 5, e1000640. [CrossRef]

116. Favoreel, H.W.; Van Minnebruggen, G.; Nauwynck, H.J.; Enquist, L.W.; Pensaert, M.B. A tyrosine-based motif in the cytoplasmic tail of pseudorabies virus glycoprotein B is important for both antibody-induced internalization of viral glycoproteins and efficient cell-to-cell spread. J. Virol. 2002, 76, 6845-6851. [CrossRef]

117. Granstedt, A.E.; Bosse, J.B.; Thiberge, S.Y.; Enquist, L.W. In vivo imaging of alphaherpesvirus infection reveals synchronized activity dependent on axonal sorting of viral proteins. Proc. Natl. Acad. Sci. USA 2013, 110, E3516-E3525. [CrossRef]

118. Brideau, A.D.; Card, J.P.; Enquist, L.W. Role of pseudorabies virus Us9, a type II membrane protein, in infection of tissue culture cells and the rat nervous system. J. Virol. 2000, 74, 834-845. [CrossRef] [PubMed]

119. Husak, P.J.; Kuo, T.; Enquist, L.W. Pseudorabies virus membrane proteins gI and gE facilitate anterograde spread of infection in projection-specific neurons in the rat. J. Virol. 2000, 74, 10975-10983. [CrossRef] [PubMed]

120. Yang, M.; Card, J.P.; Tirabassi, R.S.; Miselis, R.R.; Enquist, L.W. Retrograde, transneuronal spread of pseudorabies virus in defined neuronal circuitry of the rat brain is facilitated by $\mathrm{gE}$ mutations that reduce virulence. J. Virol. 1999, 73, 4350-4359. [CrossRef] [PubMed]

121. Schmelz, M. Itch Processing in the Skin. Front. Med. 2019, 6, 167. [CrossRef] [PubMed]

122. Iyengar, S.; Ossipov, M.H.; Johnson, K.W. The role of calcitonin gene-related peptide in peripheral and central pain mechanisms including migraine. Pain 2017, 158, 543-559. [CrossRef] [PubMed]

123. Wang, X.F.; Ge, T.T.; Fan, J.; Yang, W.; Cui, R.J. The role of substance P in epilepsy and seizure disorders. Oncotarget 2017, 8, 78225-78233. [CrossRef] [PubMed]

124. Mueller, N.H.; Gilden, D.H.; Cohrs, R.J.; Mahalingam, R.; Nagel, M.A. Varicella zoster virus infection: Clinical features, molecular pathogenesis of disease, and latency. Neurol. Clin. 2008, 26, 675-697. [CrossRef]

125. Tanaka, T.; Narazaki, M.; Kishimoto, T. IL-6 in inflammation, immunity, and disease. Cold Spring Harb. Perspect. Biol. 2014, 6, a016295. [CrossRef]

126. Yang, P.; Wen, H.; Ou, S.; Cui, J.; Fan, D. IL-6 promotes regeneration and functional recovery after cortical spinal tract injury by reactivating intrinsic growth program of neurons and enhancing synapse formation. Exp. Neurol. 2012, 236, 19-27. [CrossRef]

127. Yong, K.L. Granulocyte colony-stimulating factor (G-CSF) increases neutrophil migration across vascular endothelium independent of an effect on adhesion: Comparison with granulocyte-macrophage colony-stimulating factor (GM-CSF). Br. J. Haematol. 1996, 94, 40-47. [CrossRef]

128. Shaw, S.K.; Owolabi, S.A.; Bagley, J.; Morin, N.; Cheng, E.; LeBlanc, B.W.; Kim, M.; Harty, P.; Waxman, S.G.; $\mathrm{Saab}, \mathrm{C} . Y$. Activated polymorphonuclear cells promote injury and excitability of dorsal root ganglia neurons. Exp. Neurol. 2008, 210, 286-294. [CrossRef] [PubMed]

129. Jung, W.J.; Lee, S.Y.; Choi, S.I.; Kim, B.K.; Lee, E.J.; In, K.H.; Lee, M.G. Toll-like receptor expression in pulmonary sensory neurons in the bleomycin-induced fibrosis model. PLoS ONE 2018, 13, e0193117. [CrossRef]

130. Rietdijk, C.D.; Garssen, J.; Kraneveld, A.D. Neuronal toll-like receptors and neuro-immunity in Parkinson's disease, Alzheimer's disease and stroke. Neuroimmunol. Neuroinflamm. 2016, 3, 27-37. [CrossRef]

131. Kim, D.; Kim, M.A.; Cho, I.H.; Kim, M.S.; Lee, S.; Jo, E.K.; Choi, S.Y.; Park, K.; Kim, J.S.; Akira, S.; et al. A critical role of toll-like receptor 2 in nerve injury-induced spinal cord glial cell activation and pain hypersensitivity. J. Biol. Chem. 2007, 282, 14975-14983. [CrossRef]

132. Koyuncu, O.O.; Song, R.; Greco, T.M.; Cristea, I.M.; Enquist, L.W. The number of alphaherpesvirus particles infecting axons and the axonal protein repertoire determines the outcome of neuronal infection. MBio 2015, 6, e00276-15. [CrossRef] [PubMed]

133. De Regge, N.; Van Opdenbosch, N.; Nauwynck, H.J.; Efstathiou, S.; Favoreel, H.W. Interferon alpha induces establishment of alphaherpesvirus latency in sensory neurons in vitro. PLoS ONE 2010, 5, e13076. [CrossRef]

134. Pol, J.M.; Broekhuysen-Davies, J.M.; Wagenaar, F.; La Bonnardiere, C. The influence of porcine recombinant interferon-alpha 1 on pseudorabies virus infection of porcine nasal mucosa in vitro. J. Gen. Virol. 1991, 72, 933-938. [CrossRef] [PubMed]

135. Van Opdenbosch, N.; De Regge, N.; Van Poucke, M.; Peelman, L.; Favoreel, H.W. Effects of interferon on immediate-early mRNA and protein levels in sensory neuronal cells infected with herpes simplex virus type 1 or pseudorabies virus. Vet. Microbiol. 2011, 152, 401-406. [CrossRef] [PubMed] 
136. Song, R.; Koyuncu, O.O.; Greco, T.M.; Diner, B.A.; Cristea, I.M.; Enquist, L.W. Two Modes of the Axonal Interferon Response Limit Alphaherpesvirus Neuroinvasion. MBio 2016, 7, e02145-15. [CrossRef]

137. Lamote, J.A.S.; Kestens, M.; Van Waesberghe, C.; Delva, J.; De Pelsmaeker, S.; Devriendt, B.; Favoreel, H.W. The Pseudorabies Virus Glycoprotein gE/gI Complex Suppresses Type I Interferon Production by Plasmacytoid Dendritic Cells. J. Virol. 2017, 91, e02276-16. [CrossRef]

138. Wang, J.; Wang, C.F.; Ming, S.L.; Li, G.L.; Zeng, L.; Wang, M.D.; Su, B.Q.; Wang, Q.; Yang, G.Y.; Chu, B.B. Porcine IFITM1 is a host restriction factor that inhibits pseudorabies virus infection. Int. J. Biol. Macromol. 2019. [CrossRef] [PubMed]

139. Liu, H.; Li, S.; Yang, X.; Wang, X.; Li, Y.; Wang, C.; Chen, L.; Chang, H. Porcine ISG15 modulates the antiviral response during pseudorabies virus replication. Gene 2018, 679, 212-218. [CrossRef] [PubMed]

140. Gnann, J.W., Jr. Varicella-zoster virus: Atypical presentations and unusual complications. J. Infect. Dis. 2002, 186, S91-S98. [CrossRef] [PubMed]

141. Kost, R.G.; Straus, S.E. Postherpetic neuralgia-Pathogenesis, treatment, and prevention. N. Engl. J. Med. 1996, 335, 32-42. [CrossRef] [PubMed]

142. Acosta, E.P.; Balfour, H.H., Jr. Acyclovir for treatment of postherpetic neuralgia: Efficacy and pharmacokinetics. Antimicrob. Agents Chemother. 2001, 45, 2771-2774. [CrossRef] [PubMed]

143. Bennett, G.J.; Watson, C.P. Herpes zoster and postherpetic neuralgia: Past, present and future. Pain Res. Manag. 2009, 14, 275-282. [CrossRef]

144. Latremoliere, A.; Woolf, C.J. Central sensitization: A generator of pain hypersensitivity by central neural plasticity. J. Pain 2009, 10, 895-926. [CrossRef]

145. Semionov, V.; Shvartzman, P. Post herpetic itching-A treatment dilemma. Clin. J. Pain 2008, $24,366-368$. [CrossRef]

146. Haberthur, K.; Messaoudi, I. Animal models of varicella zoster virus infection. Pathogens 2013, 2, 364-382. [CrossRef]

147. Jarosinski, K.W.; Carpenter, J.E.; Buckingham, E.M.; Jackson, W.; Knudtson, K.; Moffat, J.F.; Kita, H.; Grose, C. Cellular Stress Response to Varicella-Zoster Virus Infection of Human Skin Includes Highly Elevated Interleukin-6 Expression. Open Forum. Infect. Dis. 2018, 5, ofy118. [CrossRef]

(C) 2020 by the authors. Licensee MDPI, Basel, Switzerland. This article is an open access article distributed under the terms and conditions of the Creative Commons Attribution (CC BY) license (http://creativecommons.org/licenses/by/4.0/). 